\title{
Diversity and Control of Spoilage Fungi in Dairy Products: An Update
}

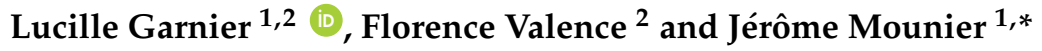 \\ 1 Laboratoire Universitaire de Biodiversité et Ecologie Microbienne (LUBEM EA3882), Université de Brest, \\ Technopole Brest-Iroise, 29280 Plouzané, France; lucille.garnier@univ-brest.fr \\ 2 Science et Technologie du Lait et de l'Euf (STLO), AgroCampus Ouest, INRA, 35000 Rennes, France; \\ florence.valence-bertel@inra.fr \\ * Correspondence: jerome.mounier@univ-brest.fr; Tel.: +33-(0)2-90-91-51-00; Fax: +33-(0)2-90-91-51-01
}

Received: 10 July 2017; Accepted: 25 July 2017; Published: 28 July 2017

\begin{abstract}
Fungi are common contaminants of dairy products, which provide a favorable niche for their growth. They are responsible for visible or non-visible defects, such as off-odor and -flavor, and lead to significant food waste and losses as well as important economic losses. Control of fungal spoilage is a major concern for industrials and scientists that are looking for efficient solutions to prevent and/or limit fungal spoilage in dairy products. Several traditional methods also called traditional hurdle technologies are implemented and combined to prevent and control such contaminations. Prevention methods include good manufacturing and hygiene practices, air filtration, and decontamination systems, while control methods include inactivation treatments, temperature control, and modified atmosphere packaging. However, despite technology advances in existing preservation methods, fungal spoilage is still an issue for dairy manufacturers and in recent years, new (bio) preservation technologies are being developed such as the use of bioprotective cultures. This review summarizes our current knowledge on the diversity of spoilage fungi in dairy products and the traditional and (potentially) new hurdle technologies to control their occurrence in dairy foods.
\end{abstract}

Keywords: spoilage; fungi; dairy products; control; diversity

\section{Introduction}

Since people began producing and storing food products, spoilage and food losses and waste became important issues for human with regards to food safety and security. Nowadays, up to one third of all food is spoiled or squandered before consumption, which represents about 1.3 billion tons per year [1]. These losses are the results of one or more problems occurring in the supply chain, from initial agricultural production down to the consumer level [1]. Concerning food spoilage, a food product can be physically, chemically, or microbiologically spoiled. Parasites, bacteria, and/or fungi are the main agents causing microbial spoilage. Certain parasites and bacteria are of public health concern because they are common contaminants of foods and are often responsible for food outbreaks. Nonetheless, being ubiquitous in nature, fungi are also very common in food. For a long time, besides altering food properties, they were not regarded as particularly detrimental to human health, although Claviceps purpurea has been related to ergotism outbreaks in the Middle Ages more than 200 years ago [2]. It is only in recent times that several mycotoxins produced by certain fungal species have been regarded as a major threat to human and animal health, especially in developing countries, being responsible for different adverse health effects [3].

Yeasts and molds are able to grow in a large variety of food including raw materials such as cereals, vegetables, fruits, meat, and milk, as well as processed products [4]. Given this large variety, 
fungal spoilage leads to severe economic losses for food manufacturers. Indeed, it is estimated that between $5 \%$ and $10 \%$ of the world's food production is lost due to fungal deterioration [2]. Dairy products are less susceptible to fungal spoilage than other products, such as fruits or vegetables, because they are usually kept at refrigerated temperatures, are often made with heat-treated milk, and some of them are fermented products meaning that they may possess a competitive microbiota, have an acidic $\mathrm{pH}$, and naturally contain organic acids. Nonetheless, a significant number of fungal species are able to survive and grow in dairy products. This astonishing adaptation capacity may be explained by the ability of fungi to utilize numerous substrates including carbohydrates, organic acids, proteins, and lipids that are present in milk and its derived products [5]. Moreover, these fungi are acidotolerant, xerotolerant, and/or psychrotolerant, and to some extent can tolerate chemical preservatives, which are sometimes added to increase product shelf-life. It is worth mentioning that several fungal species such as Debaryomyces hansenii, Candida catenulata, Galactomyces geotrichum, Kluyveromyces marxianus, Mucor lanceolatus, Penicillium roqueforti, Penicillium camemberti, or Saccharomyces cerevisiae are deliberately added as technological adjunct cultures to manufacture dairy products including kefir-type products and many kinds of cheese varieties [6-8]. Concerning undesirable species, their presence in dairy products may result in several types of food spoilage, e.g., visible growth of the fungus at the product surface, and the production of metabolites causing off-odors and flavors, as well as visible changes in color and/or texture [9]. In addition to organoleptic properties' deterioration, spoilage molds such as Penicillium and Aspergillus spp. can also produce mycotoxins $[4,5,10,11]$. In milk and dairy products, aflatoxin M1 (AFM1), which is produced by certain Aspergillus species, is the only mycotoxin for which maximum levels (0.05 ppb in the European Union (EU)) have been established. The occurrence of AFM1 in milk results from the conversion by dairy animals, fed on aflatoxin B1 (AFB1)-contaminated feedstuffs, of AFB1 to AFM1, which then pass to their urine and milk. Other mycotoxins such as ochratoxin A, citrinin, roquefortin C, mycophenolic, and cyclopiazonic acids have also been detected in cheeses at various concentrations [10]. Except for AFM1, intake of mycotoxins from dairy products is generally considered of limited importance compared to cereals and their derived products, and no human case of food poisoning related to mycotoxins has been documented so far.

Control of fungal spoilage is a major concern for industrials and scientists that are looking for efficient solutions to prevent and/or limit fungal growth or development in dairy products. Different traditional methods, also called traditional hurdle technologies, are implemented to control such contaminations including air treatment, cleaning and disinfection procedures, heat treatment, water activity reduction by brining, refrigeration, modified atmosphere packaging [12], as well as the use of chemical preservatives which are considered as food additives. The spoilage frequency and rate of many dairy foods can be reduced or retarded by the application of one or more of these treatments. However, fungal spoilage is still an issue for dairy manufacturers. Indeed, increasing fungal resistance toward heat treatments or chemical preservatives $[13,14]$ and consumers' demand for more "natural" products, as well as legislation evolution have led industrial dairy producers to find complementary control approaches. This situation has led to the development of new (bio) preservation technologies such as the use of bioprotective cultures [15].

This review summarizes our current knowledge on spoilage fungi in dairy products with a special emphasis on their diversity, as well as the traditional and (potentially) new hurdle technologies to control their occurrence in dairy products.

\section{Diversity of Spoilage Fungi in Dairy Products}

With the use of multilocus sequencing of DNA regions with taxonomical interest, fungal taxonomy has undergone important changes during the last fifteen years. Many species have been reclassified and new phylogenetic species are also being regularly recognized within so-called "species complexes," in which members only harbor few differences in their morphological characters or are even morphologically undistinguishable from each other. For fungal identification, the internal transcribed spacer region (ITS) has been chosen as the best universal barcode [16]. Concerning yeast 
identification, the D1/D2 domain of the $28 \mathrm{~S}$ rRNA gene is also widely used. It is worth mentioning that these genes are not always sufficient to identify isolates at the species level, and sequencing of other genes can be required. This is especially true for members of the Aspergillus, Cladosporium, Penicillium, and Phoma genera.

Over the years, the microbial diversity of milk and fermented dairy products has received considerable attention, and the development of next-generation sequencing (NGS) technologies [17-22] offers novel and rapid methods to characterize food ecosystems. However, except for raw milk, these techniques are not widely used to investigate fungal spoilage of dairy products because spoilage is generally the consequence of the outgrowth of a few species at the same time and because contamination can also occur on a distinct spot of the product surface. In addition, because read length is still limited with the currently used NGS technologies and because the taxonomic resolution of a single barcode marker can vary among taxa, it can be very tricky to identify operational taxonomic units (OTUs) at the species level. Nevertheless, these techniques offer new possibilities to investigate the potential sources of fungi in the dairy environment, which constitutes an important source of spoilage microorganisms.

\subsection{Sources of Fungal Contamination}

Fungal contamination of dairy foods can occur at different stages, from dairy farms to dairy processing units and at consumers' homes. Independent of the animal species, raw milk generally contains between 3 to $5 \log 10 \mathrm{CFU} \cdot \mathrm{mL}^{-1}$ fungi with higher number of yeast cells than fungal spores [23,24]. As shown by a recent study [25], the stable and milking parlor environments at the farm are important sources of fungi in the milk. In addition, an important yeast source is the teat surface [25]. It should be mentioned that yeast growth during milk storage is rare, as yeasts are rapidly outnumbered by psychrotrophic bacteria such as Pseudomonas spp. [26,27]. Moreover, except for a few fungal species, yeast and molds are not heat-resistant and should be killed after pasteurization. Therefore, during manufacturing, fungal contamination generally occurs after milk heat-treatment. Mold spoilage is often due to airborne fungi because fungal spores are easily dispersed into the dairy plant air [28]. In a recent study undertaken in a Greek dairy plant, fungal counts of $362.3 \mathrm{CFU} / \mathrm{m}^{3}$ consisting mainly of mold spores were reported in outdoor air samples while $69.8 \mathrm{CFU} / \mathrm{m}^{3}$ and $266.2 \mathrm{CFU} / \mathrm{m}^{3}$ wer found in samples from two indoor locations [29]. Recent studies [28-33] investigated the fungal diversity of the dairy environment in different dairy plants, and mold contaminations were also shown to originate from the air. In the case of sliced cheese, the cheese rind itself can also be a source of spoilage fungi which are transferred during cheese slicing to the cheese slice surface and will grow during storage at the retailer or at the consumer's home [30]. In contrast, yeast causing spoilage generally originates from brine, surface, equipment, or ingredient contaminations [32,34-36], but can also be detected in the air [29]. The brine used for cheese salting/curing is one of the most significant sources of fungi. In one study [32], counts of $1.10^{9} \mathrm{CFU} / \mathrm{cm}^{2}$ were reported in a brining tank. Moreover, ingredients such as fruit preparations can also be important contamination sources for both yeast and molds $[4,37]$. In addition, certain fruit preparations such as blueberries and strawberries are even more at risk as they do not support extensive heat-treatment [38]. It is also worth mentioning that $50-100 \%$ fruit preparations including lemon cells, strawberries, and blueberries were recently reported to contain heat-resistant ascospore-forming fungi [39]. Finally, packaging materials may also be a source of spoilage molds, despite the fact that it has not been extensively studied.

Athough there has been limited research on the subject, fungal contaminations are also likely to occur at the consumer's home after product opening. In a recent study on 586 surface samples collected from $~ 293$ refrigerators in Italy [40], 15\% and 5\% of total samples contained fungal populations $>1 \log 10$ $\mathrm{CFU} \cdot \mathrm{cm}^{-2}$ and $>2.5 \log 10 \mathrm{CFU} \cdot \mathrm{cm}^{-2}$, respectively. Besides refrigerator surfaces, cross-contamination from one product to another can also be responsible for fungal contamination. For example, mold- and smear-ripened cheeses as well as vegetables and fruits are potential yeast and mold contamination sources. Finally, the indoor air at a consumer's home is also a potent source of spoilage molds. 


\subsection{Spoilage Yeasts}

Dairy food spoilage caused by yeast can result in visible alterations mainly due to their outgrowth on the product surface, such as the "toad skin" defect caused by G. geotrichum or browning reaction caused by Yarrowia lipolytica. The latter defect is due to the extracellular accumulation of homogentisic acid, an intermediate of tyrosine catabolism, capable of auto-oxidization and polymerization, leading to the formation of pyomelanin, a brown pigment [41,42]. Yeast spoilage may also lead to detectable but non-visible alterations resulting in off-odor and -flavor or texture alterations through the production of ethanol, $\mathrm{CO}_{2}$, and volatile organic compounds (primary and secondary alcohols, aldehydes, esters) as well as the production of lipolytic and proteolytic enzymes (glycolysis). One should keep in mind that the extent of spoilage depends on two parameters: the minimal spoilage level and the chemical spoilage index, which represent the concentrations of specific spoilage organism(s) and that of spoilage metabolites determined at the time of sensory rejection, respectively [43]. In relation to yeast spoilage in dairy products, little data are available on these values. It was defined that yeasty and fermented off-flavors were detected when yeasts grew at populations equal or above $10^{5}-10^{6} \mathrm{CFU} / \mathrm{g}$ [9].

It is also worth mentioning that certain yeasts species are able to produce biogenic amines (BA) including histamine and tyramine [44-46]. For example, Y. lipolytica was responsible for histidine, lysine, ornithine, phenylalanine, and tyrosine decarboxylation, leading to the production of putrescine, 2-phenylethylamine, tyramine, and cadaverine, respectively, in a traditional Italian cheese [44]. However, the main BA producers in dairy products are bacteria including lactic acid bacteria (LAB) and enterobacteria, particularly with the formation of histamine and tyramine [47]. Interestingly, it has already been shown that G. geotrichum was able to slightly degrade BA such as tyramine [48].

A significant number of studies have been performed to assess spoilage yeast diversity (Table 1). These contaminations can be due to one or several species. For example, a recent study showed that up to 14 different yeast species could be encountered in as low as six fresh cheese samples, including cases of multi-contaminations [49]. Until now, more than 60 yeast species have been identified as spoilage agents of dairy products (Table 1). They belong to the Ascomycota and Basidiomycota phylum represented by 20 and 10 genera, respectively. Among Ascomycota, all identified species belong to the Saccharomycotina subdivision and Saccharomycetes class, which is the only class of this subdivision. Among this class, the genus Candida is the most frequently reported, representing half of the Ascomycota diversity, and is also characterized by a high diversity at the species level. Indeed, 24 different Candida species have already been reported as responsible for dairy product spoilage. Candida parapsilosis is the most frequently isolated species, followed by Candida lusitaniae, Candida inconspicua, and Candida intermedia. All these species can thus be considered common contaminants of dairy products. Table 1 also shows that dairy products spoiled by Candida are principally unripened products and hard or semi-hard cheeses such as Scamorza or Caciotta.

Besides Candida spp., Debaryomyces, Kluyveromyces, Yarrowia, Galactomyces, and Saccharomyces spp. are also frequent spoilers of fresh dairy products (fresh cheese, cream, and yoghurt) and heat-treated products (Table 1). The presence of spoilage yeasts in the latter products is principally due to post-heat-treatment contaminations, but certain yeast species show high resistance to pasteurization [50] (see Section 3.2.1). Contrary to the genus Candida, one or two species from each genus are considered dairy spoilage agents. Indeed, the Kluyveromyces genus is represented by Kluyveromyces marxianus and Kluyveromyces lactis. Debaryomyces, Galactomyces, Saccharomyces, and Yarrowia genera are represented by D. hansenii, G. geotrichum, S. cerevisiae, and Y. lipolytica, respectively. Other Ascomycota yeasts responsible for spoilage include Meyerozyma (formerly Pichia) and Pichia, Geotrichum, Dekkera, Torulaspora, Wickerhamomyces, Blastodendrion, Cyberlindnera, Kazachstania, Peterozyma, Priceomyces, and Torulopsis spp., principally isolated from soft and unripened dairy products such as fresh cheese or yoghurt.

Among Basidiomycota, six genera and four genera belonging to the Agaromycotina and Pucciniomycotina subdivisions are regularly encountered in spoiled dairy products. Among Pucciniomycotina, the genus Rhodotorula (Microbotryomycetes class), represented by three different 
species, i.e., Rhodotorula diffluens, Rhodotorula glutinis, and Rhodotorula mucilaginosa, is the most frequently cited and is essentially isolated from unripened products (Table 1). The latter genus is followed by Cryptococcus (Tremellomycetes class), represented by four species, i.e., Cryptococcus humicola, Cryptococcus laurentii, Cryptococcus pseudolongus, and Cryptococcus minuta isolated from unripened products (fresh cheese and butter/margarine) and soft cheese (Table 1). Other Basidiomycota genera include Saitozyma, Naganishia, Cutaneotrichosporon, Sporobolomyces, Sporodiobolus, Trichosporon, and Vanjira spp.

Table 1. Diversity of spoilage yeasts in dairy products.

\begin{tabular}{|c|c|c|c|}
\hline Phylum & Species & Product Types & References \\
\hline \multirow[t]{51}{*}{ Ascomycota } & Atelosaccharomyces pseudotropicalis & Yoghurt & [26] \\
\hline & Blastodendrion arztii & Fresh unripened cheese & [51] \\
\hline & Candida acidothermophilum & Yoghurt & {$[26,36,52]$} \\
\hline & Candida apis & Hard or semi-hard cheese & [53] \\
\hline & Candida beverwijkiae & Hard or semi-hard cheese & [51] \\
\hline & & Yoghurt & [26] \\
\hline & Candida blankii & Heat-treated milk and dairy product & [53] \\
\hline & Candida glabrata & Soft and semi-soft cheese & [51] \\
\hline & Candida glaebosa & Hard or semi-hard cheese & [54] \\
\hline & Candida inconspicua & Buffalo, goat, or sheep cheese & [51] \\
\hline & & Fresh unripened cheese & {$[49,51]$} \\
\hline & & Soft and semi-soft cheese & [51] \\
\hline & Candida intermedia & Hard or semi-hard cheese & {$[2,54]$} \\
\hline & & Other dairy products & [49] \\
\hline & & Yoghurt & [26] \\
\hline & Candida krusei & Soft and semi-soft cheese & [26] \\
\hline & Candida lusitaniae & Buffalo, goat, or sheep cheese & [51] \\
\hline & & Fresh unripened cheese & [51] \\
\hline & & Soft and semi-soft cheese & [51] \\
\hline & & Yoghurt & {$[26,52]$} \\
\hline & Candida multigemmis & Hard or semi-hard cheese & {$[2,54]$} \\
\hline & Candida mycoderma & Buffalo, goat, or sheep cheese & [51] \\
\hline & Candida norvegica & Soft and semi-soft cheese & [11] \\
\hline & Candida parapsilosis & Fresh unripened cheese & [51] \\
\hline & & Hard or semi-hard cheese & {$[2,51,54]$} \\
\hline & & Soft and semi-soft cheese & {$[11,49,51]$} \\
\hline & & Yoghurt & {$[2,49]$} \\
\hline & Candida pseudoglaebosa & Raw milk & [27] \\
\hline & Candida rugosa & Soft and semi-soft cheese & [11] \\
\hline & Candida saitoana & Yoghurt & [26] \\
\hline & Candida sake & Fresh unripened cheese & [55] \\
\hline & & Hard or semi-hard cheese & [54] \\
\hline & Candida sphaerica & Fresh unripened cheese & [26] \\
\hline & Candida stellata & Hard or semi-hard cheese & {$[53]$} \\
\hline & & Yoghurt & {$[26,53]$} \\
\hline & Candida versatilis & Yoghurt & {$[26,36]$} \\
\hline & Candida zeylanoides & Fresh unripened cheese & [51] \\
\hline & & Hard or semi-hard cheese & [51] \\
\hline & & Soft and semi-soft cheese & [51] \\
\hline & Candida sp. & Mold ripened cheese & [26] \\
\hline & Cyberlindnera jadinii & Soft and semi-soft cheese & [11] \\
\hline & Debaryomyces hansenii & Blue-veined cheese & [26] \\
\hline & & Buffalo, goat, or sheep cheese & [51] \\
\hline & & Fresh unripened cheese & {$[51,53,55]$} \\
\hline & & Hard or semi-hard cheese & {$[26,49,51]$} \\
\hline & & Heat-treated milk and dairy product & {$[26,52,53]$} \\
\hline & & Other dairy products & {$[52,53]$} \\
\hline & & Soft and semi-soft cheese & {$[11,51]$} \\
\hline & & Mold ripened cheese & [26] \\
\hline & & Yoghurt & {$[2,26,36,52,53]$} \\
\hline & Dekkera anomala & Fresh unripened cheese & [55] \\
\hline
\end{tabular}


Table 1. Cont.

\begin{tabular}{|c|c|c|c|}
\hline Phylum & Species & Product Types & References \\
\hline & & Yoghurt & [26] \\
\hline & Exophiala sp. & Fresh unripened cheese & [49] \\
\hline & \multirow{4}{*}{ Galactomyces geotrichum } & Butter and margarine & [2] \\
\hline & & Fresh unripened cheese & {$[2,49,55]$} \\
\hline & & Heat-treated milk and dairy product & [2] \\
\hline & & Other dairy products & [49] \\
\hline & Geotrichum capitatum & Soft and semi-soft cheese & [51] \\
\hline & Geotrichum klebahnii & Hard or semi-hard cheese & [51] \\
\hline & \multirow[t]{2}{*}{ Geotrichum sp. } & Buffalo, goat, or sheep cheese & [56] \\
\hline & & Raw milk & [57] \\
\hline & Kazachstania unispora & Soft and semi-soft cheese & [11] \\
\hline & Kluyveromyces lactis & Fresh unripened cheese & {$[49,55]$} \\
\hline & \multirow{9}{*}{ Kluyveromyces marxianus } & Blue-veined cheese & [26] \\
\hline & & Fresh unripened cheese & {$[26,53]$} \\
\hline & & Hard or semi-hard cheese & {$[26,53,54]$} \\
\hline & & Heat-treated milk and dairy product & {$[26,53]$} \\
\hline & & Mold ripened cheese & {$[26]$} \\
\hline & & Other dairy products & [52] \\
\hline & & Raw milk & [27] \\
\hline & & Soft and semi-soft cheese & [49] \\
\hline & & Yoghurt & {$[2,26,36,53]$} \\
\hline & \multirow[t]{4}{*}{ Meyerozyma guilliermondii } & Buffalo, goat, or sheep cheese & [51] \\
\hline & & Fresh unripened cheese & {$[49]$} \\
\hline & & Soft and semi-soft cheese & {$[11,51]$} \\
\hline & & Yoghurt & [49] \\
\hline & Naumovia dairenensis & Soft and semi-soft cheese & [11] \\
\hline & Peterozyma toletana & Yoghurt & {$[36]$} \\
\hline & Pichia fermentans & Soft and semi-soft cheese & {$[11,49]$} \\
\hline & \multirow[t]{2}{*}{ Pichia membranifaciens } & Fresh unripened cheese & [26] \\
\hline & & Soft and semi-soft cheese & [11] \\
\hline & Pichia norvegensis & Soft and semi-soft cheese & [11] \\
\hline & Priceomyces carsonii & Hard or semi-hard cheese & [54] \\
\hline & \multirow{8}{*}{ Saccharomyces cerevisiae } & Blue-veined cheese & [26] \\
\hline & & Buffalo, goat, or sheep cheese & {$[51]$} \\
\hline & & Fresh unripened cheese & {$[51,53]$} \\
\hline & & Hard or semi-hard cheese & [53] \\
\hline & & Heat-treated milk and dairy product & [26] \\
\hline & & Other dairy products & {$[52]$} \\
\hline & & Soft and semi-soft cheese & {$[11,51]$} \\
\hline & & Yoghurt & {$[26,36,53]$} \\
\hline & \multirow[t]{2}{*}{ Torulaspora delbrueckii } & Fresh unripened cheese & [51] \\
\hline & & Soft and semi-soft cheese & [11] \\
\hline & Torulopsis sp. & Yoghurt & [26] \\
\hline & \multirow[t]{2}{*}{ Wickerhomomyces anomalus } & Soft and semi-soft cheese & [11] \\
\hline & & Yoghurt & [2] \\
\hline & \multirow[t]{8}{*}{ Yarrowia lipolytica } & Blue-veined cheese & [26] \\
\hline & & Buffalo, goat, or sheep cheese & [51] \\
\hline & & Butter and margarine & {$[53]$} \\
\hline & & Fresh unripened cheese & {$[26,55]$} \\
\hline & & Hard or semi-hard cheese & {$[2,49,51,54]$} \\
\hline & & Mold ripened cheese & {$[2,26]$} \\
\hline & & Soft and semi-soft cheese & {$[11,49]$} \\
\hline & & Yoghurt & [2] \\
\hline \multirow[t]{11}{*}{ Basidiomycota } & \multirow[t]{2}{*}{ Cryptococcus humicola } & Butter and margarine & [2] \\
\hline & & Hard or semi-hard cheese & [2] \\
\hline & \multirow[t]{2}{*}{ Cryptococcus laurentii } & Butter and margarine & [53] \\
\hline & & Fresh unripened cheese & {$[26,53]$} \\
\hline & Cryptococcus pseudolongus & Fresh unripened cheese & [49] \\
\hline & \multirow[t]{2}{*}{ Cryptococcus sp. } & Heat-treated milk and dairy products & [52] \\
\hline & & Soft and semi-soft cheese & [11] \\
\hline & Cystobasidium minuta & Soft and semi-soft cheese & [11] \\
\hline & \multirow{3}{*}{$\begin{array}{l}\text { Cutaneotrichosporon curvatus } \\
\text { Cutaneotrichosporon cutaneum }\end{array}$} & Raw milk & [26] \\
\hline & & Hard or semi-hard cheese & [51] \\
\hline & & Fresh unripened cheese & [51] \\
\hline
\end{tabular}


Table 1. Cont.

\begin{tabular}{|c|c|c|c|}
\hline Phylum & Species & Product Types & References \\
\hline & \multirow[t]{4}{*}{ Naganishia albida } & Butter and margarine & [53] \\
\hline & & Fresh unripened cheese & [53] \\
\hline & & Other dairy products & [53] \\
\hline & & Yoghurt & [53] \\
\hline & \multirow[t]{5}{*}{ Rhodotorula diffluens } & Butter and margarine & [53] \\
\hline & & Fresh unripened cheese & [53] \\
\hline & & Hard or semi-hard cheese & {$[26,53]$} \\
\hline & & Heat-treated milk and dairy products & {$[26,52,53]$} \\
\hline & & Yoghurt & {$[2,26,53]$} \\
\hline & \multirow[t]{4}{*}{ Rhodotorula glutinis } & Butter and margarine & [53] \\
\hline & & Fresh unripened cheese & [53] \\
\hline & & Other dairy products & {$[52,53]$} \\
\hline & & Soft and semi-soft cheese & [11] \\
\hline & \multirow[t]{5}{*}{ Rhodotorula mucilaginosa } & Butter and margarine & [53] \\
\hline & & Fresh unripened cheese & {$[51,53]$} \\
\hline & & Other dairy products & {$[52,53]$} \\
\hline & & Soft and semi-soft cheese & [49] \\
\hline & & Yoghurt & {$[2,36]$} \\
\hline & Rhodotorula sp. & Heat-treated milk and dairy products & [26] \\
\hline & \multirow[t]{4}{*}{ Saitozyma flava } & Fresh unripened cheese & [53] \\
\hline & & Hard or semi-hard cheese & [53] \\
\hline & & Heat-treated milk and dairy products & {$[26,53]$} \\
\hline & & Other dairy products & [53] \\
\hline & Sporobolomyces roseus & Fresh unripened cheese & [26] \\
\hline & Sporodiobolus salmonicolor & Hard or semi-hard cheese & [49] \\
\hline & Trichosporon asahii & Soft and semi-soft cheese & [49] \\
\hline & Vanrija humicola & Fresh unripened cheese & [51] \\
\hline
\end{tabular}

\subsection{Molds in Dairy Products}

Dairy product spoilage by molds also consists in visible alterations due to the outgrowth of a thallus on the product surface. In vacuum-packed cheeses such as cheddar cheese, another defect called thread mold defect is sometimes encountered and is characterized by mold growth in folds and wrinkles of the plastic film in which the cheese is packaged [54]. Mold spoilage can also lead to the formation of off-flavors. For example, Moniliella suaveolens and Cladosporium herbarum were shown to produce ketones causing rancidity defect in butter while Penicillium glabrum, Penicillium expansum, Penicillium chrysogenum, and Cladosporium cladosporioides produced off-flavors including 2-methylisoborneol and geosmin which possess strong musty and earthy notes [2]. Interestingly, a study [58] showed that certain fungal species were able to metabolize sorbate salts (used as preservatives) to produce metabolites such as trans-1,3-pentadiene or trans-piperylene, resulting in the formation of plastic-like or "kerosene" off-flavors.

Molds responsible for dairy product spoilage are highly diverse at the genus and species levels (Table 2). Indeed, up to 100 mold species have been identified so far as being responsible for dairy product spoilage. Most species belong to the Ascomycota and Mucoromycota phyla (Table 2). Both Ascomycota and Mucoromycota have been principally isolated from hard or semi-hard cheeses.

Among Ascomycota, all identified spoilage molds (88 species distributed in 26 genera) belong to the Pezizomycotina subdivision, with the exception of Lecanicillium lecanii [59]. Within the Pezizomycotina subdivision, the Eurotiomycetes class is the most represented (nine genera and 57 species), followed by the Dothideomycetes (10 genera and 20 species), the Sordariomycetes (11 species of six genera) and the Leotiomycetes (one species). Among Eurotiomycetes, Penicillium is by far the most frequently reported spoilage genus with $\sim 40$ species, followed by Aspergillus (10 species). Other genera include Byssochlamys, Eupenicillium, Eurotium, Exophiala, Hamigera, Neosartorya, Rhinocladiella, and Talaromyces spp. 
Penicillium spp. are mainly isolated from hard and semi-hard cheeses but are also found in all other product types including fresh, blue-veined, mold-ripened, soft- and semi-soft cheeses, butter, yoghurt, milk as well as in buffalo, goat, or ewe's milk cheeses. Based on the classification system recently proposed by Houbraken and Samson [60], Penicillium spp. responsible for spoilage mainly belong to the Fasciculata section (11 species) but also to the Chrysogena (three species), Biverticillium (four species), Brevicompacta (three species) and Aspergilloides (two species) sections. Among the Fasciculata section, Penicillium commune, Penicillium solitum, Penicillium crustosum, and Penicillium verrucosum are frequently reported, while within the Chrysogena section, P. chrysogenum, Penicillium nalgiovense, and Penicillium griseofulvum are quite common. Within Brevicompacta, Penicillium brevicompactum is frequently reported, in addition to Penicillium bialowiezense [49] and Penicillium spathulatum [61]. Nonetheless, Samson et al. [62] underlined that P. bialowiezense could have been misidentified in previous studies with the closely related species P. brevicompactum. The Penicillium species mentioned above are adaptive to low temperatures, and several of them are considered xerophilic species [2], therefore, their occurrence in spoiled dairy products is not surprising. Penicillium spp. is also well-adapted to the cheese environment and has been associated with cheese manufacturing for centuries. In addition, a recent study highlighted the presence of not previously mentioned xerophilic species such as Penicillium charlesii, Penicillium fellutanum, Penicillium adametzioides, and Penicillium antarcticum [49].

Fungi from the Dothideomycetes class are principally isolated from hard and semi-hard cheeses and constitute the second most frequently identified class after Eurotiomycetes. Among this class, Cladosporium, with seven species distributed in three different Cladosporium complexes, is the most frequently reported. Cladosporium spp. grow slowly but are very common airborne fungi and are quite psychrotolerant and xerotolerant [2].

Among the Mucoromycotina sub-phylum, three different genera have already been isolated from contaminated dairy products, i.e., Mucor (four species), Rhizopus (one species), and Thamnidium (one species), all belonging to the Mucorales order. As for other genera belonging to the Ascomycota phylum, these genera were mostly isolated from spoiled cheeses [56,62,63].

Molds can also contaminate heat-treated dairy products. Indeed, species belonging to Aspergillus, Byssochlamys, Cladosporium, Eupenicillium, Fusarium, Hamigera, Neosartorya, Penicillium, and Talaromyces genera have been isolated from pasteurized milk, cream cheese, and heat-treated dairy beverages $[2,49,57]$. The presence of mold in heat-treated milk or dairy products might be due to post-processing contaminations during bottling or packaging [57] or to the heat-resistance of mold spores. Indeed, Pitt and Hocking (2009) isolated heat-resistant species such as Byssochlamys nivea (anamorph Paecilomyces niveus), Eupenicillium brefeldianum, Hamigera avellanea, and Neosartorya fischeri (anamorph Aspergillus fischeri) from cream cheese, as well as B. nivea, N. fischeri, and Talaromyces macrosporus from heat-treated dairy beverage [2]. In a recent study, it was shown that the dormancy of Talaromyces and Neosartorya spp. ascospores was broken during thermal processing, for which heat-treatment was not optimized for ascospore inactivation [64].

In addition, fungal spoilage of dairy products obtained by Ultra-High Temperature (UHT) treatment can also occur, but it is generally due to post-processing contaminations. For example, Fusarium oxysporum was isolated on several occasions from UHT-flavored milk beverages [2]. 
Table 2. Diversity of spoilage filamentous fungi isolated from contaminated dairy products.

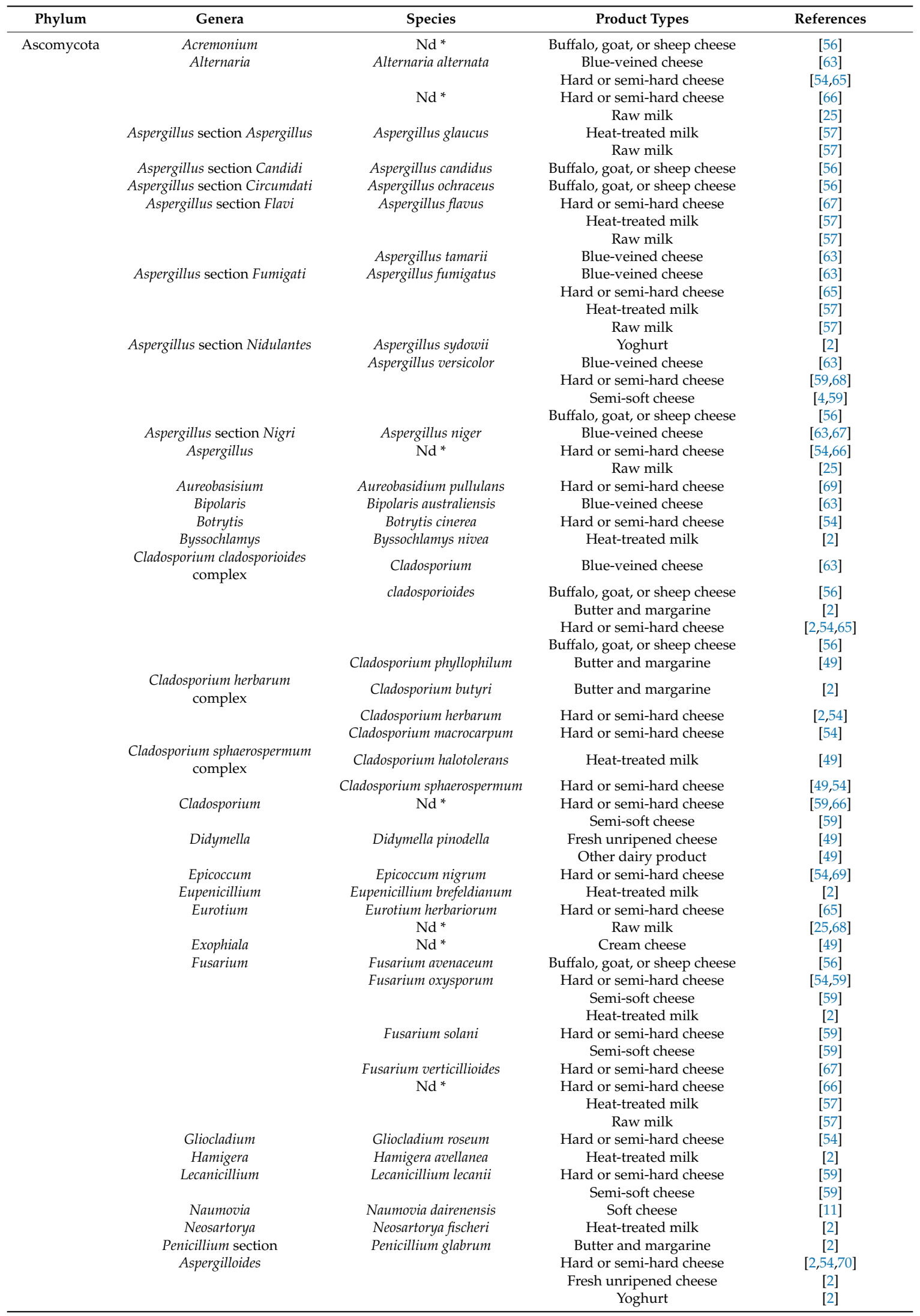


Table 2. Cont.

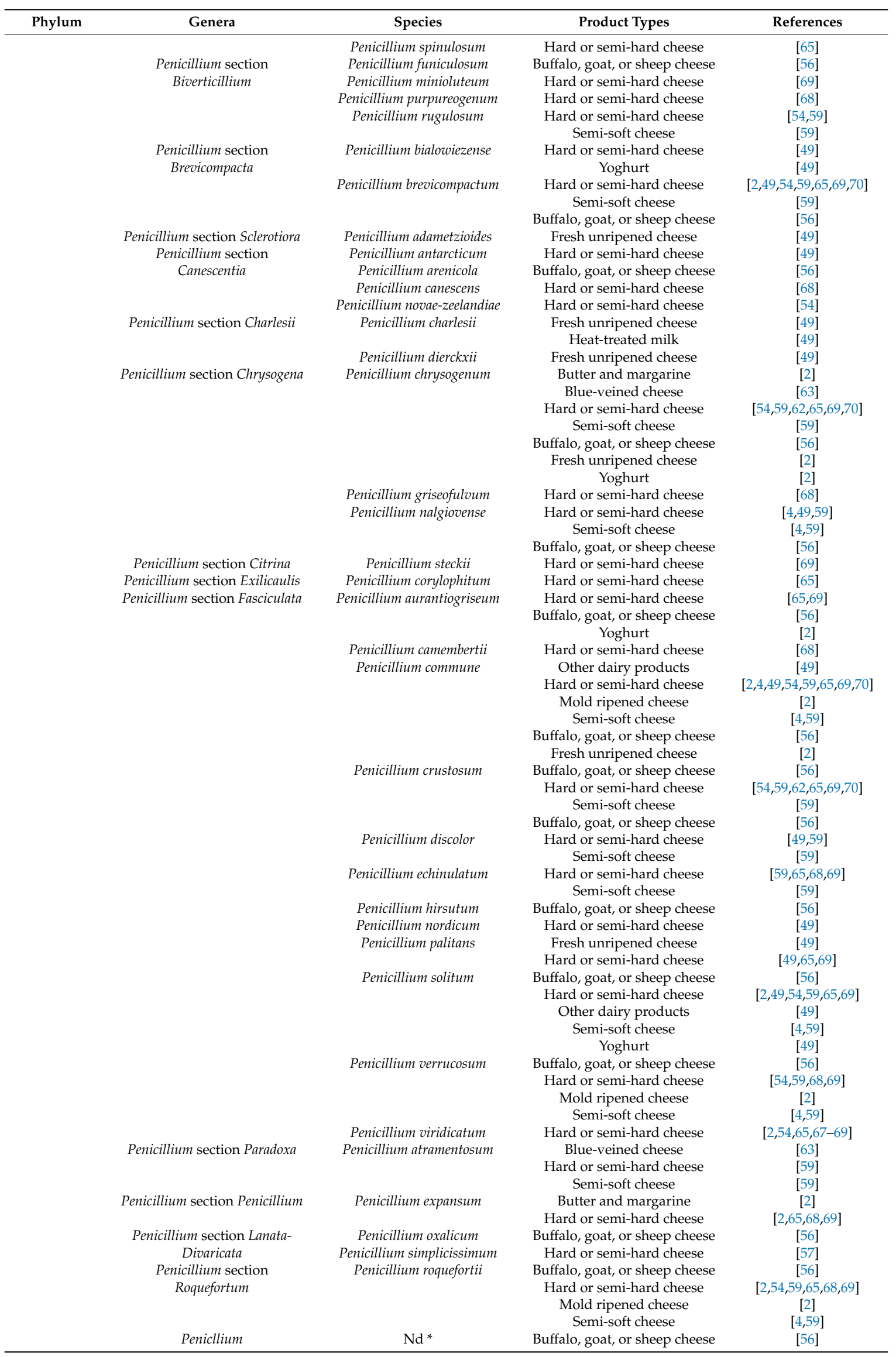


Table 2. Cont.

\begin{tabular}{|c|c|c|c|c|}
\hline Phylum & Genera & Species & Product Types & References \\
\hline & & & Heat-treated milk & [57] \\
\hline & & & Raw milk & {$[25,57]$} \\
\hline & Phoma & Phoma glomerata & Hard or semi-hard cheese & {$[2,70]$} \\
\hline & & Phoma nebulosa & Hard or semi-hard cheese & [69] \\
\hline & & $\mathrm{Nd}^{*}$ & Buffalo, goat, or sheep cheese & [56] \\
\hline & Sarocladium & Sarocladium strictum & Hard or semi-hard cheese & [69] \\
\hline & Scopulariopsis & Scopulariopsis brevicaulis & Buffalo, goat, or sheep cheese & {$[56]$} \\
\hline & & & Hard or semi-hard cheese & {$[51,59]$} \\
\hline & & & Semi-soft cheese & {$[4,59]$} \\
\hline & & $\mathrm{Nd}^{*}$ & Hard or semi-hard cheese & {$[54,67]$} \\
\hline & Talaromyces & Talaromyces macrosporus & Heat-treated milk & [2] \\
\hline \multirow{11}{*}{ Zygomycota } & & & Yoghurt & [2] \\
\hline & & Mucor hiemalis & Buffalo, goat, or sheep cheese & {$[56]$} \\
\hline & & & Hard or semi-hard cheese & {$[2,65,70]$} \\
\hline & & & Yoghurt & [2] \\
\hline & & Mucor plumbeus & Hard or semi-hard cheese & {$[65,69]$} \\
\hline & & Mucor racemosus & Hard or semi-hard cheese & {$[49,59,65,68,69]$} \\
\hline & & & Semi-soft cheese & [59] \\
\hline & & & Yoghurt & [2] \\
\hline & Rhizopus & Rhizopus stolonifer & Blue-veined cheese & [63] \\
\hline & & & Buffalo, goat, or sheep cheese & [56] \\
\hline & Thamnidium & Thamnidium elegans & Hard or semi-hard cheese & [49] \\
\hline
\end{tabular}

\section{Prevention and Control of Fungal Spoilage in Dairy Products}

Today, fungal spoilage continues to be a major challenge for industrials and, in modern practices, both preventive and control approaches are usually combined to reduce its incidence in dairy foods (Figure 1). Preventive methods can be defined as methods which can avoid contamination or recontamination during product processing, including packaging in aseptic conditions, use of air filtration system, and good manufacturing practices such as good hygienic practices and Hazard Analysis and Critical Control Points (HACCP) system implementation [71]. Control methods involve the use of methods which will either slow down or inhibit microbial growth, such as the addition of chemical preservatives, use of modified atmosphere packaging, and low temperature storage, as well as methods which will inactivate fungi such as heat and high-pressure treatments [71].

When it comes to choosing the most appropriate preventive and control methods, different factors must be taken into account. One major factor is the characteristics of the product to be preserved (composition, $\mathrm{a}_{\mathrm{w}}$ ) and those of the microorganisms of concern as well as the sanitation conditions along the manufacturing process and product storage conditions. Another important factor is also consumer perception and acceptance of food preservation methods as well as their impact on hygiene and safety and their associated cost [72,73]. That is probably the reason why, among emerging methods to combat fungal spoilage, the use of bioprotective cultures and fermentates to decrease the use of chemical preservatives is gaining more and more attention [74]. 


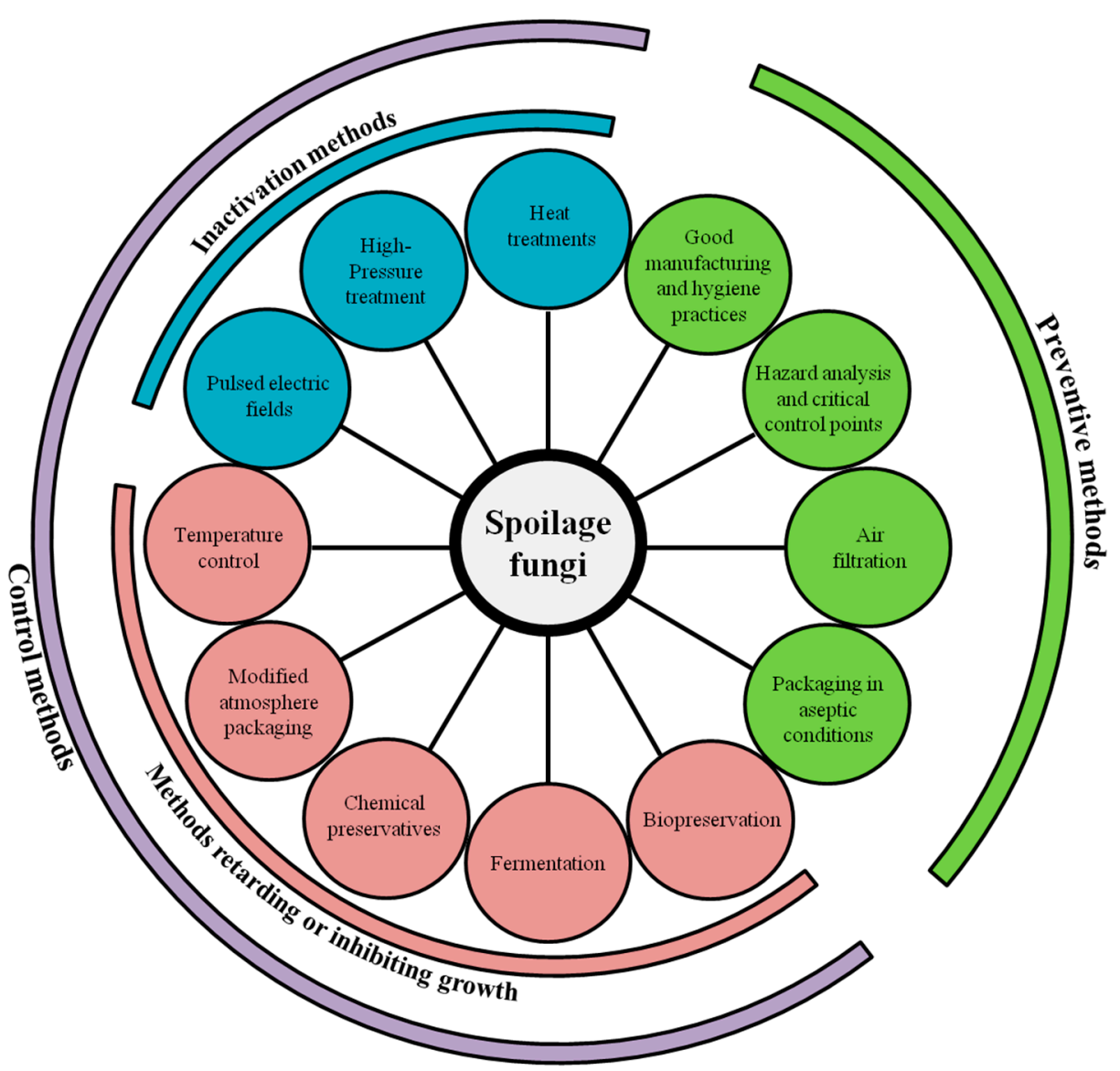

Figure 1. Preventive and control methods used in dairy products for preventing, inactivating, retarding, or inhibiting growth of spoilage fungi.

\subsection{Preventive Methods}

\subsubsection{Good Manufacturing and Distribution Practices}

The success of any food preservation method depends on low initial levels of contamination, which in turn are achieved through the application of appropriate cleaning, sanitation, decontamination, and hygienic practices [73]. Dairy product manufacturing and packaging must also be done in the most hygienic and aseptic conditions possible to reduce the risk of biological contamination including that of fungal contamination [75,76]. In a code of good manufacturing and distribution practices (GMDPs), two main points are essential: (1) selecting good quality raw materials and monitoring the manufacturing process to control microbes while preventing cross-contamination; and (2) avoiding or retarding microbial growth [77,78]. GMDPs are an indispensable part of every food quality system. This code relies on the use of good hygiene practices and on the implemented hazard analysis critical control point (HACCP) systems from the production to the consumption of dairy products. In accordance with the Codex Alimentarius indications and Regulation 852/2004/CE, HACCP systems identify, evaluate, and control hazards that threaten food hygiene, in particular taking into account the microbiological risks $[79,80]$. Thus, the microbiological quality of dairy products is controlled at each step of the production process, from the raw materials to the finished product [81]. Prerequisite programs, such as Total Quality Management (TQM), a method including planning, organizing, and understanding each activity and involving each individual at each level, or Just-In-Time (JIT), a program designed to reduce waste by reducing flow times within the production system as well as response times from suppliers and to customers, are useful to improve product 
quality $[81,82]$. These programs have significant costs and require important efforts, but will produce return in investment in the long term.

\subsubsection{Air Filtration and Decontamination Systems}

With specific regard to the fungal contamination risk, potential contamination sources include ambient air. Therefore, efficient air-filtration systems should be in place to reduce spore counts into the air where the product is vulnerable. For example, Beletstiotis et al. [29] showed that the operation of High Efficiency Particulate Air (HEPA) filters class 10.000, designed to withhold fungal spores, allowed a decrease in fungal loads by 30 times in the indoor air of a dairy plant. The direction of air flows and location of outlets should also be carefully examined in sensitive zones. Moreover, the control of air pressurization can be applied to prevent air flow from the dirtiest to cleanest areas. Cleanroom technologies (aseptic or ultraclean technologies) including minienvironments that protect equipment such as filling and packaging equipment, transport system tunnels, or protective enclosures can also be used.

For air decontamination, gaseous ozone was successfully applied for disinfecting empty cheese ripening and storage facilities with up to a 10-fold reduction in mold and yeast counts depending on the dose and treatment time [83,84], see for a review Varga and Szigeti, 2016 [85]. Finally, molds and yeasts are able to grow in humid zones (walls, ceiling, and floor) and on the equipment if these are not properly cleaned and disinfected.

Various disinfectants such as alcohol, peracetic acid, iodophors, aldehydes, quaternary amine compounds, chlorine-based agents, or hydrogen peroxide have been used in the dairy industry against fungal contaminations. Nonetheless, fungal response to such cleaning agents varies with disinfectant type and concentration. For example, Korukluoglu et al. [86] showed that Aspergillus niger was sensitive to alcohol but not to peracetic acid; moreover, $A$. niger was resistant to $0.5 \%$ iodophor but sensitive at $1 \%$. In addition, Bundgaard-Nielsen and Nielsen (1995) demonstrated the existence of intraspecific variation in tolerance to quaternary ammonium compounds, especially in P. commune and Penicillium nalgiovense [87]. Finally, Martin et al. [88] revealed that the combination of hydrogen peroxide and formic acid had a synergistic action against Scopulariopsis brevicaulis and G. geotrichum, thus showing that a combination of different disinfectants is a possible solution to prevent fungal contaminations. More work is required to investigate the efficiency of disinfectant agents against fungi in the dairy product context, while taking into account the continuously evolving legislation on their use.

\subsection{Control Methods}

\subsubsection{Inactivation Treatments}

Concerning heat-treatments, thermization, pasteurization, and UHT sterilization are intended to partially or completely reduce milk microbial load while altering as little as possible milk organoleptic and nutritional properties [89]. During such heat-treatment, the product is subjected to a high temperature for a short period of time. In the EU, thermization, pasteurization, and UHT correspond to treatments at $57-68{ }^{\circ} \mathrm{C}$ for a minimum of $15 \mathrm{~s}, 71.7{ }^{\circ} \mathrm{C}$ for $15 \mathrm{~s}$, and at least $135{ }^{\circ} \mathrm{C}$ for a few seconds, respectively [90]. According to Sakkas et al. [91], the efficacy of heat treatments are related to the temperature-time combinations, heating method utilized, and milk pre-treatment conditions (filtration, homogenization, standardization, etc.). Concerning milk thermization, the main objective is to reduce the population of spoilage microorganisms and to inactivate enzymes while minimizing heat damage to milk components. Milk pasteurization is much more efficient than thermization, but not all microorganisms can be destroyed and this treatment has to be followed by a rapid chilling $\left(4^{\circ} \mathrm{C}\right)$ to slow down subsequent microbial growth. Finally, UHT sterilization, used for milk and dairy drinks, is itself obtained by applying a continuous heat-flow for a short time-period which allows for the total destruction of microorganisms followed by milk aseptic packaging [87]. 
As mentioned earlier, certain fungal species, because of their considerable heat-resistance, are able to spoil heat-treated dairy products, in particular pasteurized fruit-based products. Heat-resistant species include Byssochlamys spectabilis, N. fischeri, H. avellanea, and Talaromyces bacillisporus [92,93]. This feature is due to their heat-resistant ascospores which are activated when heat-treatments are not high enough to inactivate them. As an example, $N$. fischeri and T. bacillisporus were shown to possess decimal reduction times at $85{ }^{\circ} \mathrm{C}\left(\mathrm{D}_{85}\right)$ ranging from 15.0 to $30.1 \mathrm{~min}$, and from 11.9 and $15.5 \mathrm{~min}$, respectively [39,94]. N. fischeri and T. bacillisporus showed $\mathrm{D}_{85}$ ranging from 47 to $75 \mathrm{~min}$ in $\mathrm{N}$-(2-Acetamido)-2-aminoethanesulfonic acid buffer as well as $\mathrm{D}_{90}$ ranging from 7.5 to $12.7 \mathrm{~min}$ and $\mathrm{D}_{95}$ ranging from 0.56 to $0.67 \mathrm{~min}$ in blueberry juice [95]. They showed $\mathrm{D}_{90}$ from 2.0 to $7.6 \mathrm{~min}$ and $\mathrm{D}_{95}$ from 1.7 to $2.3 \mathrm{~min}$ in juices. N. fischeri and T. bacillisporus showed $\mathrm{D}_{87}$ from 11.1 to $66.7 \mathrm{~min}, \mathrm{D}_{90}$ from 4.7 to $13.5 \mathrm{~min}$, and $\mathrm{D}_{95}$ from 0.43 to $1.52 \mathrm{~min}$ and ranged between 44.4 and $60.9 \mathrm{~min}$ at $82{ }^{\circ} \mathrm{C}$ and 2.7 and $4.1 \mathrm{~min}$ at $88^{\circ} \mathrm{C}$. As another example, $\mathrm{H}$. avellanea ascospores are activated but not destroyed after heat-treatment for $20 \mathrm{~min}$ at $87^{\circ} \mathrm{C}, 5 \mathrm{~min}$ at $90^{\circ} \mathrm{C}$, and $1 \mathrm{~min}$ at $95^{\circ} \mathrm{C}$, showing the importance of time-temperature conditions treatment [93].

Other techniques such as high-pressure (HP) treatments of dairy products can also be used to inactivate yeast cells and mold spores (among other microorganisms) and extend product shelf-life [95]. Mainville et al. [96] and Reps et al. [97] showed that yeasts from kefir were completely inactivated at $400 \mathrm{MPa}$ for $15 \mathrm{~min}$ or $30 \mathrm{~min}$ without significant changes in protein and lipid structure of the product. Moreover, Evert-Arriagada et al. [98] recently demonstrated that HP processing under industrial conditions could extend the shelf-life of a commercial starter-free fresh cheese. Pressurized cheeses were firmer and more yellow than control cheeses, but these changes did not affect the panel preference for pressurized cheese. It is worth mentioning that there is an increasing number of HP-treated dairy products available on the market as this technology meets consumer's expectations for more "natural" and less-heavily processed food products.

Pulsed electric fields (PEF) treatment consists of pulsed electric fields of strong intensity (15 to $50 \mathrm{kV} / \mathrm{cm}$ ) for only few seconds [99]; this represents another emerging technology for microbial inactivation, including that of yeast and molds, with potential application in fluid dairy foods (see the recent reviews of Buckow et al. [100] and Wan et al. [101]).

\subsubsection{Temperature Control}

Temperature control is critical for dairy food quality and shelf-life. Cold temperatures are used to minimize microbial growth in raw milk until processing and to extend the shelf-life of non-sterile dairy foods. Low temperatures, or even frozen storage, however, do not eliminate microorganisms [73]. Milk and dairy products are generally stored between $0{ }^{\circ} \mathrm{C}$ and $4{ }^{\circ} \mathrm{C}$ and at temperatures ranging from 4 to $10^{\circ} \mathrm{C}$ at the consumer's home. However, most fungi are psychrotrophic and are thus able to grow at such temperatures. In a recent study, Gougouli et al. [102] evaluated the effect of temperature and inoculum size on the growth of one isolate each from 12 fungal species during yoghurt storage. The ability to grow at refrigerated temperature was species-dependent with estimated minimal growth temperatures of -6.7 and $9.6^{\circ} \mathrm{C}$ for $P$. commune and A. niger, respectively. In addition, Gougouli et al. [102] also developed and validated a probabilistic model to predict the appearance of visible mycelia originating from single spores which could be used for choosing adequate conditions for challenge tests. It should be noted that besides storage temperature and the spoilage organism itself, fungal spoilage susceptibility depends on the spoiler initial population and the time required to form a visible thallus on the product surface, which can be predicted using predictive mycology tools.

\subsubsection{Modified Atmosphere Packaging}

Modified atmosphere packaging (MAP) is a commonly used method to control fungal spoilage and thus to extend dairy food shelf-life. MAP consists of the replacement of air by a defined gas mixture. In MAP, active agents such as carbon dioxide [103] or oxygen scavengers [104] can also 
be utilized. During storage, passive modifications of the headspace gases can occur, resulting from product respiration and gas transfer through the film.

As extensively reviewed by Nguyen Van Long et al. [105] on a large number of fungal species, lowering the oxygen level below $1 \%$ will result in the partial growth inhibition of strict aerobic fungi, while it will slow down facultative anaerobes' growth as it enables $\mathrm{O}_{2}$ use as a final electron acceptor. However, for many species including Penicillium and Mucor spp., only $0 \% \mathrm{O}_{2}$ concentration can totally inhibit growth [105]. It is worth mentioning that such an $\mathrm{O}_{2}$ level will favor the growth of facultative or strict anaerobes and that it can have a detrimental effect on products such as mold-ripened cheeses, for which a certain oxygen level is necessary to maintain their organoleptic properties [106]. An increase of the $\mathrm{CO}_{2}$ level in package atmosphere can have an inhibitory effect, thus further extending product shelf-life [105]. In their extensive review, Nguyen Van Long et al. [105] indicated that, independent of the fungal species, a $\mathrm{CO}_{2}$ level above $50 \%$ was necessary to achieve fungal growth inhibition and that, depending on the fungal species, $50-90 \%$ were necessary to completely inhibit fungal growth in solid matrices. Three mechanisms have been described to explain the $\mathrm{CO}_{2}$ antimicrobial effect. The first mechanism is the displacement of some or all of the $\mathrm{O}_{2}$ available for growth of aerobic microorganisms. The second one is a $\mathrm{pH}$ decrease resulting from $\mathrm{CO}_{2}$ dissolution into the product and carbonic acid formation. Carbonic acid will then behave as a weak organic acid provoking disturbances in $\mathrm{pH}$ homeostasis $[107,108]$. Nonetheless, high $\mathrm{CO}_{2}$ concentration may sometimes affect product organoleptic al properties. For example, high $\mathrm{CO}_{2}$ levels $(100 \%)$ led to very negative effects in the sensory qualities of cottage cheese, whereas for others, such as cheddar, packaging with $100 \% \mathrm{CO}_{2}$ is commonly used in dairy industries [109,110].

MAPs are often used for cheeses and different gas compositions have been suggested [109,111,112]. For example, in commercial sliced cheddar cheese, P. commune did not grow in atmospheres composed either of $20 \%, 40 \%$, and $60 \% \mathrm{CO}_{2}$ and less than $0.5 \% \mathrm{O}_{2}$ [113]. Eurotium chevalieri and Xeromyces bisporus could not grow under atmosphere containing $80 \% \mathrm{CO}_{2}$ and $20 \% \mathrm{O}_{2}$ during incubation for 60 days, whereas Mucor plumbeus development was observed after 15 days [111]. Facultative anaerobic fungi are also susceptible to high $\mathrm{CO}_{2}$ levels [113-115]. As an example, a $60 \% \mathrm{CO}_{2} / 40 \% \mathrm{~N}_{2}$ modified atmosphere was effective for inhibiting yeast growth and extending the shelf-life of whey cheese [113].

A good temperature control is necessary for effective MAP use because the $\mathrm{CO}_{2}$ effect is enhanced as the temperature decreases. A combination of refrigeration and the storage of milk and milk products under modified gas atmospheres for the extension of shelf life has been reviewed extensively [108,116-118]. In general, most of the used atmospheres do not completely inhibit growth, but the spoilage time is delayed. Overall, more research is needed to improve our knowledge on $\mathrm{O}_{2}$ and $\mathrm{CO}_{2}$ effects on the germination and growth of spoilage fungi and, thus, to improve MAP efficiency.

\subsubsection{Chemical Preservatives}

In addition to the methods mentioned above, chemical preservatives are widely used in the dairy industry. Preservatives are food additives that help to prevent dairy products from spoilage by bacteria and/or fungi. Antifungal preservatives used in dairy products include weak organic acids, such as sorbic acid, benzoic acid, and propionic acid, and their salts, such as potassium sorbate, calcium sorbate, sodium benzoate, potassium benzoate, calcium benzoate, and sodium propionate, as well as natamycin, a polyethylene antibiotic (Table 3). 
Table 3. List and regulations of chemical preservatives authorized in dairy products in the European Union (EU) [119] and the United States of America (USA) [120].

\begin{tabular}{|c|c|c|c|c|c|}
\hline Preservatives & Dairy Product & USA Regulation & $\begin{array}{l}\text { Food and Drug } \\
\text { Administration } \\
\text { (FDA) Code }\end{array}$ & EU Legislation & EU Code \\
\hline \multirow[t]{2}{*}{ Natamycin (pimaricin) } & Cheese & $20 \mathrm{mg} / \mathrm{kg}$ & 172.155 & - & - \\
\hline & Uncut hard, semi-hard, and semi-soft cheese & $20 \mathrm{mg} / \mathrm{kg}$ & 172.155 & $\begin{array}{l}1 \mathrm{mg} / \mathrm{dm}^{2} \text {, surface }(\mathrm{not} \\
\text { present at a depth of } 5 \mathrm{~mm})\end{array}$ & E 235 \\
\hline \multirow[t]{5}{*}{ Sorbic acid } & Margarine & $1000 \mathrm{mg} / \mathrm{kg}$ & 182.3089 & - & \multirow{5}{*}{ E 200} \\
\hline & Flavoured fermented milk & $2000 \mathrm{mg} / \mathrm{kg}$ & & $1500 \mathrm{mg} / \mathrm{kg}$ & \\
\hline & Non-heat-treated dairy-based desserts & $2000 \mathrm{mg} / \mathrm{kg}$ & & $300 \mathrm{mg} / \mathrm{kg}$ & \\
\hline & Whey cheeses, cheese products, processed cheeses & $2000 \mathrm{mg} / \mathrm{kg}$ & & $2000 \mathrm{mg} / \mathrm{kg}$ & \\
\hline & $\begin{array}{l}\text { Curdled milk, unripened products, ripened products, pre-packed, sliced; layered ripened } \\
\text { products }\end{array}$ & $2000 \mathrm{mg} / \mathrm{kg}$ & & $1000 \mathrm{mg} / \mathrm{kg}$ & \\
\hline \multirow[t]{9}{*}{$\begin{array}{l}\text { Potassium sorbate and } \\
\text { calcium sorbate }\end{array}$} & $\begin{array}{l}\text { Cold-pack cheese, cream cheese, pasteurized process cheese food, pasteurized process } \\
\text { cheese spread, semi-soft part-skim cheeses }\end{array}$ & $3000 \mathrm{mg} / \mathrm{kg}$ & 182.3640 and 182.3225 & - & \multirow[t]{9}{*}{ E 202 and E 203} \\
\hline & Flavoured fermented milk products including heat-treated products & $3000 \mathrm{mg} / \mathrm{kg}$ & & $1500 \mathrm{mg} / \mathrm{kg}$ & \\
\hline & Non-heat-treated dairy-based desserts & $3000 \mathrm{mg} / \mathrm{kg}$ & & $300 \mathrm{mg} / \mathrm{kg}$ & \\
\hline & Whey cheeses, cheese products, processed cheeses & $3000 \mathrm{mg} / \mathrm{kg}$ & & $2000 \mathrm{mg} / \mathrm{kg}$ & \\
\hline & $\begin{array}{l}\text { Curdled milk, unripened products, ripened products, pre-packed, sliced; layered ripened } \\
\text { products }\end{array}$ & $3000 \mathrm{mg} / \mathrm{kg}$ & & $1000 \mathrm{mg} / \mathrm{kg}$ & \\
\hline & Flavoured fermented milk products including heat-treated products & $3000 \mathrm{mg} / \mathrm{kg}$ & & $1500 \mathrm{mg} / \mathrm{kg}$ & \\
\hline & Non-heat-treated dairy-based desserts & $3000 \mathrm{mg} / \mathrm{kg}$ & & $300 \mathrm{mg} / \mathrm{kg}$ & \\
\hline & Whey cheeses, cheese products, processed cheeses & $3000 \mathrm{mg} / \mathrm{kg}$ & & $2000 \mathrm{mg} / \mathrm{kg}$ & \\
\hline & $\begin{array}{l}\text { Curdled milk, unripened products, ripened products, pre-packed, sliced; layered ripened } \\
\text { products }\end{array}$ & $3000 \mathrm{mg} / \mathrm{kg}$ & & $1000 \mathrm{mg} / \mathrm{kg}$ & \\
\hline \multirow[t]{5}{*}{ Sodium benzoate } & Margarine & $1000 \mathrm{mg} / \mathrm{kg}$ & 184.1733 & - & \multirow[t]{5}{*}{ E 211} \\
\hline & Flavoured fermented milk products including heat-treated products & - & & $1500 \mathrm{mg} / \mathrm{kg}$ & \\
\hline & Non-heat-treated dairy-based desserts & - & & $300 \mathrm{mg} / \mathrm{kg}$ & \\
\hline & Whey cheeses, cheese products, processed cheeses & - & & $2000 \mathrm{mg} / \mathrm{kg}$ & \\
\hline & $\begin{array}{l}\text { Curdled milk, unripened products, ripened products, pre-packed, sliced; layered ripened } \\
\text { products }\end{array}$ & - & & $1000 \mathrm{mg} / \mathrm{kg}$ & \\
\hline \multirow[t]{4}{*}{$\begin{array}{l}\text { Potassium benzoate and } \\
\text { calcium benzoate }\end{array}$} & Flavoured fermented milk products including heat-treated products & - & 184.1081 & $1500 \mathrm{mg} / \mathrm{kg}$ & \multirow{4}{*}{$\mathrm{E} 212$ and $\mathrm{E} 213$} \\
\hline & Non-heat-treated dairy-based desserts & - & & $300 \mathrm{mg} / \mathrm{kg}$ & \\
\hline & Whey cheeses, cheese products, processed cheeses & - & & $2000 \mathrm{mg} / \mathrm{kg}$ & \\
\hline & $\begin{array}{l}\text { Curdled milk, unripened products, ripened products, pre-packed, sliced; layered ripened } \\
\text { products }\end{array}$ & - & & $1000 \mathrm{mg} / \mathrm{kg}$ & \\
\hline \multirow[t]{2}{*}{ Propionic acid } & Gruyere cheese, swiss cheese, and emmentaler cheese & surface & & - & \multirow{2}{*}{ E 280} \\
\hline & Ripened cheese & - & & surface treatment & \\
\hline \multirow[t]{2}{*}{ Sodium propionate } & Cheeses and related cheese products & surface & 184.1784 & - & \multirow{2}{*}{ E 281} \\
\hline & Ripened cheese & - & & surface treatment & \\
\hline
\end{tabular}


Weak acids inhibit both bacterial and fungal growth. In addition, sorbic acid also inhibits spore germination in bacteria [121,122]. Preservatives such as benzoic and sorbic acid have an optimal inhibitory activity at $\mathrm{pH}$ between 4.5 and 5.5. Indeed, at such $\mathrm{pH}$, the uncharged, undissociated acid form can diffuse freely across the cytoplasmic membrane and enter into the cell. The equilibrium between the undissociated and dissociated forms depends on the acid $\mathrm{pKa}$ and the medium $\mathrm{pH}$. Once inside the cell ( $\mathrm{pHi} \sim 7$ ), the acid will dissociate and release charged anions and protons which cannot diffuse back across the membrane. Anions and protons accumulation into the cell is responsible for intracellular $\mathrm{pH}$ decrease and may cause membrane disruption, inhibition of essential metabolic reactions, stress in intracellular $\mathrm{pH}$ homeostasis, and/or accumulation of toxic anions which finally lead to cell death [14]. In a recent study, Garnier et al. [49] determined the minimal inhibitor concentration (MIC) of different weak acids including potassium sorbate, calcium propionate, and sodium benzoate for several fungal strains isolated from spoiled dairy products. They found that, independent of the studied species, calcium propionate was the least effective preservative followed by sodium benzoate and potassium sorbate. It should be emphasized that the inhibitory effect of weak acids on fungi is also influenced by other factors such as $\mathrm{a}_{\mathrm{w}}$. For example, the MIC of sorbic acid were $0.1 \%$ and $0.15 \%(w / w)$ at $0.85 \mathrm{a}_{\mathrm{w}}$ while they were $0.075 \%$ and $0.05 \%(w / w)$ at $0.90 \mathrm{a}_{\mathrm{w}}$, for Aspergillus flavus and P. roqueforti, respectively [123]. Moreover, Stratford et al. [124] recently showed that, in contrast to acetic acid, sorbic acid did not decrease $\mathrm{pHi}$ in S. cerevisiae but instead was a membrane-active compound, inhibiting the activity of a plasma-membrane $\mathrm{H}^{+}$-ATPase proton pump. Most studies on the action mechanism of weak acids have been performed on S. cerevisiae and Zygosaccharomyces bailli. Therefore, more studies are necessary to understand the exact inhibition mechanism of weak acids against spoilage fungi encountered in dairy products. Finally, for hard and semi-hard smear cheeses, which are characterized by the development of a red-orange microbial mat on their surfaces, films permeable to moisture and $\mathrm{O}_{2}$ can be utilized to pack the cheeses in order to protect them from yeast and molds present in the dairy environment. Such films can also be coated with antifungal molecules such as natamycin. It is worth mentioning that a successful attempt has been made to replace synthetic film polymers by a chitosan coating containing natamycin for protecting semi-hard cheese from fungal contamination [125].

Fungal resistance or adaptation to weak organic acids rely on several mechanisms. In S. cerevisiae and other fungi, it includes maintenance of the cell wall structure, changes in plasma membrane or cell wall composition, metal metabolism, and activation of ATP-consuming membrane transporters to remove protons and anions [126]. Ullah et al. [127] showed that S. cerevisiae adaptation to sorbic or acetic acid resulted in a decreased diffusional entry of the molecule. They concluded that pre-exposed cells indeed decreased acid entry through alteration of either the plasma membrane structure or the cell wall composition or through an increase in intracellular buffering capacity. In addition, Brandao et al. [38] showed that the $\mathrm{H}^{+}$internal concentration in S. cerevisiae was regulated by several systems, including plasma membrane $\mathrm{H}^{+}$-ATPase, and that ENA1p, known for its in involvement in saline or alkaline stress responses and regulation of the plasma membrane potential had an important but yet to be fully understood role in the cellular response to acid [126]. This study also demonstrated that acid stress response was dependent on calcium metabolism and was blocked by a calcineurin inhibitor. Other resistance mechanisms include the metabolization of weak acids into the cell. For example, Casas et al. [128] showed that $D$. hansenii could metabolize potassium sorbate into pentadiene, a volatile compound also responsible for off-odor, while $A$. niger was able to decarboxylate and detoxify sorbic acid thanks to a phenylacrylic acid decarboxylase [129].

Natamycin (also known as pimaricin) is a fungicide belonging to polyethylene antibiotics [130]. It is currently used to control fungal growth on cheese surfaces [131-133]. Produced by Streptomyces natalensis, this antibiotic acts by inhibiting the vacuole fusion process through specific interaction with ergosterol at the early priming stage of fusion, but does not permeabilize the membrane.

A World Health Organization (WHO) monograph on Food Additives states that obtaining resistance against natamycin is difficult, because of the action mode of these chemical agents [134]. Indeed, natamycin binds to ergosterol, an important component of the plasma membrane and of 
the growing tips of germinating spores and vegetative hyphae $[135,136]$. In addition, natamycin MIC of different fungal species were reported to only differ negligibly, which is not in favor of resistance development [134]. For example, C. parapsilosis, Rhodotorula spp., and Penicillium spp. had mean MIC of $5.2 \mu \mathrm{g} / \mathrm{mL}, 2.3 \mu \mathrm{g} / \mathrm{mL}$, and $2.3 \mu \mathrm{g} / \mathrm{mL}$, respectively [137]. In contrast, Garnier et al. [49], who evaluated natamycin MIC after surface-treatment of one isolate each of 10 species from spoiled dairy products, observed that MIC ranged from $0.04 \mathrm{mg} / \mathrm{dm}^{2}$ in Cladosporium halotolerans to $>0.2 \mathrm{mg} / \mathrm{dm}^{2}$ in Y. lipolytica. In addition, a recent study [138] showed that a continuous and prolonged incubation with natamycin induced a tolerance in individual strains.

The WHO [139], European Food Safety Authority [119], and Food and Drug Administration [120] have evaluated natamycin thoroughly and all list it as safe for human consumption. In the US, according to the Code of Federal Regulations, the final amount of natamycin must not exceed $20 \mathrm{ppm}$ in cheese $(20 \mathrm{mg} / \mathrm{kg})$. In the EU, natamycin is only allowed for cheese surface-treatment with a maximum applied dose of $1 \mathrm{mg} / \mathrm{dm}^{2}$. Moreover, it must not be present at a depth $>5 \mathrm{~mm}$ in the finished product [140].

\subsubsection{Fermentation}

Fermentation is one of the oldest preservation methods [141,142]. It is a biological process relying on the activity of specific microorganisms producing certain metabolites with antifungal and antibacterial activities [12,141]. Different microbial groups involved in dairy product manufacturing may suppress or retard the growth of spoilage fungi. LAB produce lactic acid as a major fermentation end-product, but may also produce other metabolites with antifungal activity (see also Section 4). Certain cheese types such as smear cheeses and mold-ripened cheeses also harbor on their surfaces complex microbiota composed of desirable aerobic bacteria and fungi which can compete with spoilage fungi for one or more limiting macro- and/or micronutrients and/or for space.

A complementary approach to reduce fungal spoilage in dairy products is gaining more and more interest: the use of bioprotective cultures and fermentates.

\section{Bioprotective Cultures}

Today, in more economically developed countries, there is a strong and increasing demand from consumers for foods that are more "natural", i.e., less heavily processed and preservative-free $[75,143]$. That is the reason why a strong market demand exists for natural solutions to ensure both food safety and food shelf-life [144]. Biopreservation is not a new concept as it has been used for thousands of years in fermented foods. Also called biocontrol, it refers to the extension of food shelf-life and increase in food safety using natural or added microbiota and/or their antimicrobial compounds [145]. Food bioprotective cultures can thus be defined as food-grade bacterial or fungal strains that have been selected for their antimicrobial properties. They differ from starter or adjunct cultures which are primarily used for their technological functions (acid and aroma production, role in texture, color, etc.). Among microorganisms possessing antimicrobial properties, $\mathrm{LAB}$, produce a large array of antimicrobial substances including organic acids such as lactic and acetic acids, fatty acids, reuterin, antifungal peptides, and bacteriocins [146, 147]. While research has mainly focused on screening for bacterial strains with antimicrobial activity against pathogenic or spoilage bacteria and fungi, fungi with antimicrobial activities also exist [148].

\subsection{Lactic Acid Bacteria and Propionibacteria with Antifungal Activity}

$\mathrm{LAB}$ and propionibacteria (PAB) can be used in food production as starter cultures to modify and improve nutritional and organoleptic food properties, or as protective cultures to improve product safety and/or shelf-life [144,149]. Indeed, LAB are used as starter cultures in the manufacturing of dairy products such as fermented milk, yoghurt, buttermilk, cottage cheeses, hard cheeses, and soft cheeses, among many others [150]. LAB have also been traditionally used as natural biopreservatives of food and feed, including milk and dairy products.

Antifungal LAB have been studied in a large food range including dairy products [15,151]. Today, several recent studies report the use of antifungal LAB to control dairy product spoilage $[15,152,153]$. 
LAB produce many antifungal metabolites [154] and most LAB are granted with a generally recognized as safe (GRAS) and qualified presumption of safety (QPS) status. Besides being safe for human consumption (absence of biogenic amine production and acquired antibiotic resistance), the main properties expected from antifungal LAB and PAB bioprotective cultures are: (1) an antifungal activity exhibited and maintained during manufacturing and storage; (2) no impact on starter cultures' functionalities; (3) no modification of product organoleptic properties; (4) an activity at the lowest possible inoculum to reduce the cost associated with their use; and (5) an easy propagation at high populations and resistance to lyophilization or freezing. There are currently several antifungal bioprotective cultures commercially available for dairy products, such as HoldBac series (DuPont Danisco), FreshQ ${ }^{\circledR}$ series (Dupont), and Befresh $^{\mathrm{TM}}$ AF (Handary). Holdbac YM-B is a mixed culture of Lactobacillus rhamnosus and Propionibacterium freudenreichii subsp. shermanii and Fresh $Q^{\circledR} 2$ is a single L. rhamnosus culture, while Befresh ${ }^{\mathrm{TM}} \mathrm{AF}$ is a mixture of Lactobacillus paracasei and P. freudenreichii subsp. shermanii. Despite such bioprotective cultures being available on the market, research for new LAB with antifungal activities and identification of their associated metabolites is now the focus of many academic and industrial research groups.

Screening for antifungal strains is a critical step among those required to develop antifungal cultures. For example, a recent study described a high-throughput screening method to detect antifungal activities in Lactobacillus species cultivated in Man, Rogosa, and Sharpe (MRS) media [155]. This method allowed the detection of 154 strains with antifungal activities against $R$. mucilaginosa and to a lower extent against Aspergillus tamari, Candida krusei, and K. marxianus. However, as mentioned in several papers [156,157], screening in conventional MRS medium is not recommended as MRS contains acetate which may potentialize antifungal activity and artificially inflate the number of active isolates. Another interesting but labor-consuming approach, used by Delavenne et al. [158] to develop an antifungal isolate collection, was to plate raw milk samples on eight semi-selective media for $\mathrm{LAB}$, and to systematically screen colonies for their antifungal activity against four spoilage fungi using the agar-overlay method. Among the $\sim 72,000$ tested colonies, $>-1200$ colonies (i.e., 1.7\% of tested colonies) had a detectable antifungal activity. However, one should keep in mind that laboratory media differ significantly in their physicochemical and microbiological characteristics with those of dairy foods and, thus, active strains in laboratory media may lose this ability in real products. Overall, further work is needed to develop high-throughput screening methods in dairy products mimicking models to increase the chances of finding suitable strains.

Among antifungal LAB, Lactobacillus and, to a smaller extent, Lactococcus, Pediococcus, Weissella, and Leuconostoc are the most frequently cited genera (Table 4). Indeed, many strains pertaining to species of the Lactobacillus genus including Lactobacillus plantarum, Lactobacillus casei, Lactobacillus paracasei, and Lactobacillus brevis were shown to possess antifungal activity against a large spectrum of fungal targets including Penicillium, Candida, Kluyveromyces, and Rhodotorula spp. as well as Debaryomyces hansenii and Yarrowia lipolytica, which are among the most important spoilage agents in dairy products [49]. Among Propionibacterium, P. freudenreichii is the major species reported to possess antifungal activity [157,159].

So far, besides lactic, acetic, and propionic acids, which are produced at $\mathrm{g} / \mathrm{L}$ or $\mathrm{g} / \mathrm{kg}$ levels, a very large variety of molecules has been reported to be responsible for antifungal activity. These molecules are generally produced at lower levels ( $\mathrm{mg} / \mathrm{L}$ or $\mathrm{mg} / \mathrm{kg}$ ), and include organic acids (2-pyrrolidone-5-carboxylic acid, 3-phynyllactic acid, 4-hydroxybenzoic acid, azelaic acid, DL-P-hydroxyphenyllactic acid, hydroxyphenyllactic, p-coumaric acid, phenyllactic acid (S)-(-)-2-hydrocinnamic acid, succinic acid, vanillic acid), fatty acids (3-hydroxydecanoic acid, decanoic acid, hydroxyisocapric acid), cyclopeptides (cyclo(L-Pro-L-Pro), cyclo(L-Leu-L-Pro), cyclo(L-Tyr-L-Pro) cyclo(L-Met-L-Pro), cyclo(Phe-Pro), cyclo(Phe-OH-Pro), cyclo(L-Phe-LPro), cyclo(L-Phe-trans-4-OH-L-Pro) and cyclo(L-His-L-Pro)), reuterin [160], and volatile compounds such as diacetyl [153] (Table 4). Because these molecules are produced at quantities below their MIC, it is likely that they act in synergy. For example, in a study focusing on the effect of organic acids on molds, Dagnas et al. [161] showed that lactic acid alone had almost no inhibitory effect against several mold species while lactic and acetic acids could act in synergy. 
Table 4. Lactic and propionic acid bacteria showing antifungal activities and their responsible compounds.

\begin{tabular}{|c|c|c|c|c|}
\hline $\begin{array}{l}\text { Lactic Acid Bacteria (LAB) and } \\
\text { Propionibacteria }\end{array}$ & Matrix & Metabolites & Targets & References \\
\hline \multicolumn{5}{|l|}{ Genus Lactococcus } \\
\hline \multirow[t]{5}{*}{ Lc. lactis } & Lab-Lemco tryptone broth (LTB) & $\mathrm{Nd}^{*}$ & Aspergillus flavus & [162] \\
\hline & LTB & Nisin & Aspergillus parasiticus & [163] \\
\hline & Potatoe Dextrose Agar (PDA) + 0.1\% Triton X-100 & $\mathrm{Nd}^{*}$ & Aspergillus fumigatus, A. parasiticus, A. flavus & [164] \\
\hline & PDA $+0.1 \%$ Triton X-100 & Possibly proteinaceous compound(s) & Fusarium spp., A. flavus, A. parasiticus & [165] \\
\hline & LTB and PDA & Possibly proteinaceous compound(s), lactic acid & Penicillium expansum & [166] \\
\hline \multicolumn{5}{|l|}{ Genus Lactobacillus } \\
\hline Lactobacillus spp. & De Man, Rogosa and Sharpe (MRS) agar & Acetic acid, propionic acid, lactic acid, peptides & Penicillium candidum, Debaryomyces hansenii & [167] \\
\hline \multicolumn{5}{|c|}{ Group Lb. alimentarius/Lb. farciminis } \\
\hline Lb. paralimentarus & Modified Sabouraud Dextrose Broth (mSDB) medium & Lactic acid, phenyllactic acid, acetic acid, peptides & $\begin{array}{l}\text { Aspergillus japonicus, Eurotium repens, Penicillium } \\
\text { roseopurpureum }\end{array}$ & [168] \\
\hline \multicolumn{5}{|l|}{ Group Lb. brevis } \\
\hline \multirow[t]{4}{*}{ Lb. brevis } & PDA & Peptide & Penicillium roqueforti & [169] \\
\hline & wheat flour hydrolysate (WFH) broth & Acetic acid, phenyllactic acid, lactic acid & Fusarium graminearum & [170] \\
\hline & mMRS agar & Organic acids and proteinaceous compounds & Fusarium spp. & [171] \\
\hline & MRS agar or PDA & Peptide & $\begin{array}{l}\text { Penicillium camemberti, P. roqueforti, Aspergillus } \\
\text { niger, Rhizopus oryzae, Kluyveromyces marxianus, } \\
\text { Torulopsis candida, Meyerozyma guillermondii, } \\
\text { Saccharomyces cerevisiae }\end{array}$ & [172] \\
\hline \multicolumn{5}{|l|}{ Group Lb. casei } \\
\hline \multirow[t]{4}{*}{ Lb. casei } & PDA $+0.1 \%$ Triton $\mathrm{X}-100$ & Possibly proteinaceous compound(s) & A. flavus, A. parasiticus, Fusarium sp. & [165] \\
\hline & PDA & Peptide & Penicillium citrinum, P. expansum, A. flavus & [173] \\
\hline & Yoghurt & Lactic acid and cyclo-(Leu-Pro) & Penicillium sp. & [174] \\
\hline & LTB and PDA & Possibly proteinaceous compound(s), lactic acid & P. expansum & [166] \\
\hline \multirow[t]{4}{*}{ Lb. paracasei } & Yoghurt and cheese surface & $\begin{array}{l}\text { Propionic acid, acetic acid, lactic acid, succinic acid, } \\
\text { 2-pyrrolidone-5-carboxylic acid, 3-phynyllactic acid, hydroxyphenyllactic acid }\end{array}$ & $\begin{array}{l}\text { Candida pulcherrima, Candida magnoliae, Candida } \\
\text { parapsilosis, Zygosaccharomyces bailii }\end{array}$ & [151] \\
\hline & MRS agar & Peptide & $\begin{array}{l}\text { Candida albicans, Candida blankii, Candida } \\
\text { pseudointermedia }\end{array}$ & [175] \\
\hline & Chemically defined interaction medium & Diacetyl & Penicillium solitum, Penicillium sp. & [153] \\
\hline & Yoghurt and acidified milk & Diacetyl, acetic acid, butanoic acid, 2,3-pentadione & P. solitum, Penicillium sp. & [153] \\
\hline \multirow{2}{*}{\multicolumn{5}{|c|}{ Group Lb. coryniformis }} \\
\hline & & & & \\
\hline Lb. coryniformis & MRS agar or PDA & $\begin{array}{l}\text { Peptide +/ -3 KDa, phenyllactic acid, cyclo(Phe-Pro), cyclo(Phe-OH-Pro), } \\
\text { reuterin }\end{array}$ & Broad spectrum & [147] \\
\hline \multicolumn{5}{|l|}{ Group Lb. delbrueckii } \\
\hline Lb. amylovorus & MRS broth & $\begin{array}{l}\text { 3-phenylpropanoic acid, } p \text {-coumaric, (E)-2-methylcinnamic acid, 3-phenyllactic } \\
\text { acid, 3-(4-hydroxyphenyl)lactic acid, lactic acid, acetic acid, D-glucuronic acid, } \\
\text { salicylic acid, cytidine and 2'-deoxycytidine, sodium decanoate, }\end{array}$ & A. fumigatus, Fusarium culmorum & [175] \\
\hline
\end{tabular}


Table 4. Cont.

\begin{tabular}{|c|c|c|c|c|}
\hline $\begin{array}{l}\text { Lactic Acid Bacteria (LAB) and } \\
\text { Propionibacteria }\end{array}$ & Matrix & Metabolites & Targets & References \\
\hline & Cheese & $\begin{array}{l}\text { Cyclo(L-Pro-L-Pro), cyclo(L-Leu-L-Pro), cyclo(L-Tyr-L-Pro) cyclo(L-Met-L-Pro) } \\
\text { and cyclo(L-His-L-Pro) }\end{array}$ & P. roqueforti, P. expansum & [176] \\
\hline & Milk agar and cheese & $\begin{array}{l}\text { DL-p-hydroxyphenyllactic acid, 4-hydroxybenzoic acid, } \\
\text { (S)-(-)-2-hydroxyisocapric acid, azelaic acid, phenyllactic acid, benzoic acid, } \\
\text { hydrocinnacmic acid, 3-hydroxydecanoic acid, DL- } \beta \text {-hydroxylauric acid, } \\
\text { decanoic acid, salicylic acid, 4-hydroxybenzoic, vanillic acid, } \\
\text { (S)-(-)-2-hydroxyisocapric acid }\end{array}$ & P. expansum & [177] \\
\hline Lb. delbrueckii & LTB and PDA & Possibly proteinaceous compound(s), lactic acid & P. expansum & [166] \\
\hline \multicolumn{5}{|l|}{ Group Lb. fructivorans } \\
\hline Lb. sanfranciscencis & Malt-agar medium & Caproic acid, propionic acid, butyrix acid, acetic acid, valeric acid & F. graminearum & {$[178,179]$} \\
\hline \multicolumn{5}{|c|}{ 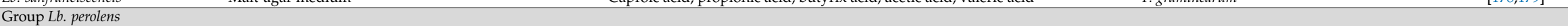 } \\
\hline Lb. harbinensis & Yoghurt & Acetic acid, lactic acid & $\begin{array}{l}\text { Yarrowia lipolytica, P. expansum, Penicillium } \\
\text { brevicompactum, D. hansenii, R. mucilaginosa, } \\
\text { Kluyveromyces lactis }\end{array}$ & {$[15,158]$} \\
\hline \multicolumn{5}{|l|}{ Group Lb. plantarum } \\
\hline \multirow[t]{2}{*}{ Lb. pentosus } & MRS & Peptide & A. niger & [180] \\
\hline & MRS agar & Peptide, phenyllactic and hydroxyphenyllactic acid & Penicillium nalgiovense, Aspergillus candidus & [181] \\
\hline \multirow[t]{11}{*}{ Lb. plantarum } & mMRS agar & $\begin{array}{l}\text { (S)-(-)-2-hydroxyisocapric acid, hydrocinnamic acid, phenyllactic acid, } \\
\text { decanoic acid, azelaic acid, 4-hydroxybenzoic acid, } p \text {-coumaric acid, vanillic } \\
\text { acid, DL-P-hydroxyphenyllactic acid, 3-hydroxydecanoic acid }\end{array}$ & $\begin{array}{l}\text { Microsporum canis, Microsporum gypseum, } \\
\text { Epidermophyton floccosum }\end{array}$ & [182] \\
\hline & MRS broth & $\begin{array}{l}\text { Benzoic acid, 5-methyl-2,4-imidazolidinedione, } \\
\text { tetrahydro-4-hydroxy-4-methyl-2H-pyran-2-one, } \\
\text { 3-(2-methylpropyl)-2,5-piperazinedione, cyclo(glycyl-L-leucyl)). }\end{array}$ & Fusarium avenaceum & [183] \\
\hline & MRS agar & Lactic acid, PLA, cyclo(L-Leu-L-Pro), cyclo(L-Phe-L-Pro) & $\begin{array}{l}\text { A. niger, F. graminearum, F. culmorum, Fusarium } \\
\text { oxysporum }\end{array}$ & [184] \\
\hline & Wheat flour hydrolysate (WFH) & Phenyllactic acid, 4-hydroxy-phenillactic acid & $\begin{array}{l}\text { E. repens, Eurotium rubrum, Penicillium corylophilum, } \\
\text { P. roqueforti, P. expansum, Endomyces fibuliger, A. } \\
\text { niger, A. flavus, Monilia sitophila, F. graminearum }\end{array}$ & [185] \\
\hline & MRS broth & $\begin{array}{l}\text { 3-phenyllactic acid, cyclo(Phe-Pro), cyclo(Phe-OH-Pro), cyclo(L-Phe-LPro) and } \\
\text { cyclo(L-Phe-trans-4-OH-L-Pro) dipeptides }\end{array}$ & Fusarium sporotrichioides, A. fumigatus, K. marxianus & [186] \\
\hline & Wheat flour hydrolysate (WFH) & Acetic acid, phenyllactic acid, lactic acid & F. graminearum, A. niger & [170] \\
\hline & MRS agar & $\begin{array}{l}\text { 3-(R)-hydroxydecanoic acid, 3-hydroxy-5-cis-dodecenoic acid, } \\
\text { 3-(R)-hydroxydodecanoic acid and 3-(R)-hydroxytetradecanoic acid }\end{array}$ & $\begin{array}{l}\text { A. fumigatus, Aspergillus nidulans, K. marxianus, } P . \\
\text { roqueforti, Penicillium commune, Penicillium anomala, } \\
\text { R. mucilaginosa }\end{array}$ & [187] \\
\hline & MRS agar plates & Acetic acid & $\begin{array}{l}\text { A. flavus, F. graminearum, Rhizopus stolonifer, } \\
\text { Sclerotium oryzae, Rhizoctonia solani, Botrytis cinerea, } \\
\text { Sclerotinia minor }\end{array}$ & [188] \\
\hline & MRS agar & Peptide, phenyl-lactic and hydroxy-phenyllactic acid & $\begin{array}{l}\text { P. nalgiovense, P. camemberti, Penicillium verrucosum, } \\
\text { Penicillium chrysogenum, A. candidus, A. flavus, A. } \\
\text { ochraceus, A. fumigatus, Galactomyces geotrichum, } \\
\text { Moniliella spp., Mucor racemosus, Wallemia sebi, } \\
\text { Eurotium herbariorum }\end{array}$ & [181] \\
\hline & Soybean & 3,6-bis(2-methylpropyl)-2,5-piperazinedion & A. flavus & [189] \\
\hline & MRS agar plates & 3-3-phenyllactic acid (PLA), lactic acid, acetic acid & A. fumigatus, Rhizopus stolonifer & [190] \\
\hline
\end{tabular}


Table 4. Cont.

\begin{tabular}{|c|c|c|c|c|}
\hline $\begin{array}{l}\text { Lactic Acid Bacteria (LAB) and } \\
\text { Propionibacteria }\end{array}$ & Matrix & Metabolites & Targets & References \\
\hline & MRS agar medium, apple-based agar growth medium & Lactic acid, acetic acid & P. expansum, Penicillium notatum & [191] \\
\hline & MRS agar medium & 2-hydroxy-4-methylpentanoic acid & $\begin{array}{l}\text { A. niger, Aspergillus tubingensis, Penicillium } \\
\text { crustosum }\end{array}$ & [192] \\
\hline & PDA plates & 3-PLA, benzeneacetic acid, 2-propenyl ester & $\begin{array}{l}\text { B. cinerea, Glomerella cingulate, Phytophthora } \\
\text { drechsleri Tucker, P. citrinum, Penicillium digitatum, } \\
\text { F. oxysporum }\end{array}$ & [193] \\
\hline & Chopped Meat Carbohydrate (CMC) broth & Lactic acid & $\begin{array}{l}\text { F. avenaceum, F. culmorum, F. graminearum, } \\
\text { F. oxyporum }\end{array}$ & [194] \\
\hline \multicolumn{5}{|l|}{ Group Lb. reuteri } \\
\hline Lb. fermentum & MRS & Peptide & A. niger & [180] \\
\hline \multirow[t]{2}{*}{ Lb. reuteri } & Wheat flour hydrolysate (WFH) broth & Acetic acid, phenyllactic acid, lactic acid & F. graminearum, A. niger & [170] \\
\hline & mMRS agar & $\begin{array}{l}\text { Acid, vanillic acid, DL-D-hydroxyphenyllactic acid, 3-hydroxydecanoic acid, } \\
\text { (S)-(-)-2-hydroxyisocapric acid, hydrocinnamic acid, phenyllactic acid, decanoic } \\
\text { acid, azelaic acid, 4-hydroxybenzoic acid, p-coumaric }\end{array}$ & M. canis, M. gypseum, E. floccosum & [182] \\
\hline Lb. rossiae & mSDB agar medium & Lactic acid, phenyllactic acid, acetic acid, peptides & A. japonicus, E. repens, P. roseopurpureum & [168] \\
\hline \multicolumn{5}{|l|}{ Group Lb. sakei } \\
\hline Lb. sakei & MRS & Sakacin KTU05-6 & $\begin{array}{l}\text { A. flavus, A. fumigatus, A. niger, Aspergillus } \\
\text { versicolor, F. culmorum, Fusarium poae, Mucor spp., } \\
\text { P. chrysogenum, P. expansum, Penicillium spp. }\end{array}$ & [195] \\
\hline \multicolumn{5}{|c|}{ 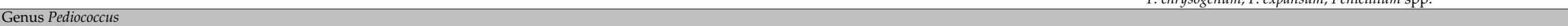 } \\
\hline Pc. acidilactici & MRS & Pediocin KTU05-08 & $\begin{array}{l}\text { A. flavus, A. fumigatus, A. niger, A. versicolor, } F \text {. } \\
\text { culmorum, F. pooe, Mucor spp., P. chrysogenum } \\
\text { P. expansum, Penicillium spp. }\end{array}$ & [195] \\
\hline \multirow[t]{4}{*}{ Pc. pentosaceous } & MRS & Peptide & A. niger & [180] \\
\hline & MRS agar plates & Acetic acid & $\begin{array}{l}\text { A. flavus, F. graminearum, R. stolonifer, S. oryzae, } \\
\text { R. solani, B. cinerea, S. minor }\end{array}$ & [188] \\
\hline & MRS & Pediocin KTU05-09, KTU05-10 and AcKTU05-67 & $\begin{array}{l}\text { A. flavus, A. fumigatus, A. niger, A. versicolor, } \\
\text { F. culmorum, F. poae, Mucor spp., P. chrysogenum, } \\
\text { P. expansum, Penicillium spp. }\end{array}$ & [195] \\
\hline & MRS agar medium & Possibly cyclic dipeptide & P. expansum, Penicillium notatum & [191] \\
\hline \multicolumn{5}{|l|}{ Genus Weissella } \\
\hline W. cibaria & MRS agar medium & Lactic acid, acetic acid & P. expansum, P. notatum & [191] \\
\hline \multirow[t]{2}{*}{ W. paramesenteroides } & MRS agar medium & 2-hydroxy-4-methylpentanoic acid, lactic acid, acetic acid & A. niger, A. tubingensis, P. crustosum & [192] \\
\hline & MRS agar plates & Acetic acid & $\begin{array}{l}\text { A. flavus, F. graminearum, R. stolonifer, S. oryzae, } \\
\text { B. cinerea, S. minor }\end{array}$ & [188] \\
\hline
\end{tabular}


Table 4. Cont.

\begin{tabular}{|c|c|c|c|c|}
\hline $\begin{array}{l}\text { Lactic Acid Bacteria (LAB) and } \\
\text { Propionibacteria }\end{array}$ & Matrix & Metabolites & Targets & References \\
\hline \multicolumn{5}{|l|}{ Genus Propionibacteria } \\
\hline \multirow[t]{4}{*}{ P. acidipropionici } & Sodium lactate (SL) medium & Lactic acid, propionic acid, acetic acid & A. fumigatus & [196] \\
\hline & MRS & Propionic acid, acetic acid & R. mucilaginosa, P. roqueforti, A. fumigatus & [196] \\
\hline & MRS-acetate & Propionic acid, acetic acid & R. mucilaginosa, $P$. roqueforti, A. fumigatus & [196] \\
\hline & SL broth & PLA & A. fumigatus & [196] \\
\hline \multirow[t]{4}{*}{ P. freudenreichii subsp. shermanii } & Skim milk & propionic acid, 3-phenyllactic acid & P. chrysogenum & [159] \\
\hline & MRS & Acetic acid, propionic acid, 3-phenyllactic acid, 4-hydroxy-phenyllactic acid & P. chrysogenum & [159] \\
\hline & MRS & Propionic acid, acetic acid & P. roqueforti, A. fumigatus & [196] \\
\hline & MRS-acetate & Propionic acid, acetic acid & R. mucilaginosa, P. roqueforti, A. fumigatus & [196] \\
\hline \multirow[t]{2}{*}{$\begin{array}{l}\text { P. freudenreichii subsp. } \\
\text { freudenreichii }\end{array}$} & MRS & Propionic acid, acetic acid & R. mucilaginosa, P. roqueforti, A. fumigatus & [196] \\
\hline & MRS-acetate & Propionic acid, acetic acid & R. mucilaginosa, $P$. roqueforti, A. fumigatus & [196] \\
\hline \multirow[t]{3}{*}{ P. jensenii } & Yoghurt and cheese surface & $\begin{array}{l}\text { Propionic acid, acetic acid, lactic acid, succinic acid, 2-pyrrolidone-5-carboxylic } \\
\text { acid, 3-phynyllactic acid, hydroxyphenyllactic acid }\end{array}$ & C. pulcherrima, C. magnollae, C. parapsilosis, Z. bailii & [151] \\
\hline & MRS & Propionic acid, acetic acid & R. mucilaginosa, $P$. roqueforti, A. fumigatus & [196] \\
\hline & MRS-acetate & $\mathrm{Nd}^{*}$ & R. mucilaginosa, P. roqueforti, A. fumigatus & [196] \\
\hline \multirow[t]{4}{*}{ P. thoenii } & Sodium Lactate (SL) medium & Lactic acid, propionic acid & A. fumigatus & [196] \\
\hline & SL broth & PLA & A. fumigatus & [196] \\
\hline & MRS & Propionic acid, acetic acid & $\begin{array}{l}\text { R. mucilaginosa, P. roqueforti, A. fumigatus, } \\
\text { K. marxianus }\end{array}$ & [196] \\
\hline & MRS-acetate & Propionic acid, acetic acid & R. mucilaginosa, P. roqueforti, A. fumigatus & [196] \\
\hline
\end{tabular}


Similar results were reported for other organic acids such as PLA, in which MIC decreased in the presence of lactic acid [185]. Only few studies [154,197] dealt with the action mode of LAB antifungal metabolites and the response of fungi at the physiological, transcriptomic, or proteomic levels. Therefore, further research should be undertaken in this area.

As shown in Table 3, most studies on LAB and PAB antifungal activity have been performed in (semi-)synthetic culture medium and it is obvious that important discrepancies can exist between in vitro and in situ tests. The main reasons for this are that intrinsic and extrinsic factors can affect the production of antifungal metabolites, their activity, and the susceptibility of the fungal target to these compounds. Intrinsic factors include medium composition in terms of macro- and micronutrients, $\mathrm{pH}$, $\mathrm{a}_{\mathrm{w}}$, Eh, and food structure, while extrinsic factors are temperature, composition of the surrounding atmosphere, and humidity. Therefore, a second critical step in developing antifungal cultures is to test their efficiency in real products using challenge- and durability-tests and against one or several fungal targets. It should be noted that only a few publications have clearly shown in situ antifungal activity of selected LAB and PAB (Table 4). For example, Delavenne et al. $[15,27]$ showed the antifungal activity of Lactobacillus harbinensis KV931Np against six fungal targets in yoghurt while Schwenninger and Meile (2004) demonstrated the antifungal activity of three mixed cultures of Lactobacillus paracasei subsp. paracasei SM20, SM29, or SM63 and Propionibacterium jensenii SM11, against Candida pulcherrima, C. magnoliae, C. parapsilosis, and Zygosaccharomyces bailii in yoghurt and on cheese surfaces [151]. More recently, Aunsbjerg et al. [153] proved the antifungal activity of Lactobacillus paracasei in chemically defined medium and in yoghurt against $P$. solitum and Penicillium sp.

\subsection{Fermentates}

$\mathrm{LAB}$ and PAB may also be used to produce dairy fermentates containing antifungal metabolites, which are fermented dairy ingredients produced from milk via a fermentation process [144]. MicroGARD (DuPont Danisco) and DuraFresh (Kerry) are two currently available commercial fermentates. As an example, MicroGARD, which is FDA-approved, is produced by skimmed milk fermentation using $P$. freudenreichii subsp. shermanii. The use of this fermentate in cottage cheese partially inhibited K. marxianus and P. expansum and thus extended its shelf-life [197]. It may also be used in sour cream, yoghurt, and dairy desserts [198].

\section{Conclusions}

Despite technological advances, fungal spoilage is still a main issue in the dairy industry. Among the actual methods in use, a large focus concerns the replacement of traditional hurdle technologies such as chemical preservatives by new techniques to meet the increasing consumer demand for less-heavily processed and preservative-free dairy products. These new techniques include preventive methods such as a better management of air quality and non-thermal control methods such as modified atmosphere packaging and biopreservation using antifungal bioprotective cultures or fermentates.

Acknowledgments: We are grateful to the regional councils of Brittany (grant No. 13008651) and Pays de la Loire (grant No. 2014-07081) for the financial support and INRA for scientific coordination (J. Leonil) through the interregional project PROFIL, managed by BBA industrial association.

Conflicts of Interest: The authors declare no conflict of interest.

\section{References}

1. FAO. Global FOOD Losses and Food Waste-Extent, Causes and Prevention. Rome. 2011. Available online: http:/ / www.fao.org/docrep/014/mb060e/mb060e00.pdf (accessed on 5 July 2017).

2. Pitt, J.I.; Hocking, A.D. Fungi and Food Spoilage, 3rd ed.; Springer Science \& Business Media: New York, NY, USA, 2009; pp. 1-2, ISBN 978-1-4615-6391-4.

3. Shephard, G.S. Impact of mycotoxins on human health in developing countries. Food Addit. Contam. A 2008, 25, 146-151. [CrossRef] [PubMed] 
4. Filtenborg, O.; Frisvad, J.C.; Thrame, U. Moulds in food spoilage. Int. J. Food Microbiol. 1996, 33, 85-102. [CrossRef]

5. Huis in't Veld, J.H.J. Microbial and biochemical spoilage of foods: An overview. Int. J. Food Microbiol. 1996, 33, 1-18. [CrossRef]

6. Prado, M.R.; Blandón, L.M.; Vandenberghe, L.P.S.; Rodrigues, C.; Castro, G.R.; Thomas-Soccol, V.; Soccol, C.R. Milk kefir: Composition, microbial cultures, biological activities and related products. Front. Microbiol. 2015, 6, 1177. [CrossRef] [PubMed]

7. Desmasures, N. CHEESE-mold-ripened varieties. In Encyclopedia of Food Microbiology, 2nd ed.; Batt, C.A., Ed.; Elsevier Inc.: Atlanta, GA, USA, 2014; pp. 409-415, ISBN 9780123847331.

8. Baroiller, C.; Schmidt, J.L. Contribution à l'étude de l'origine des levures du fromage de Camembert. Lait 1990, 70, 67-84. [CrossRef]

9. Ledenbach, L.H.; Marshall, R.T. Microbiological spoilage of dairy products. In Compendium of the Microbiological Spoilage of Foods and Beverages, Food Microbiology and Food Safety; Sperber, W.H., Doyle, M.P., Eds.; Springer: New York, NY, USA, 2010; pp. 41-67, ISBN 1441908269, 9781441908261.

10. Hymery, N.; Vasseur, V.; Coton, M.; Mounier, J.; Jany, J.L.; Barbier, G.; Coton, E. Filamentous fungi and mycotoxins in cheese: A review. Compr. Rev. Food Sci. Food Saf. 2014, 13, 437-456. [CrossRef]

11. Westall, S.; Filtenborg, O. Spoilage yeasts of decorated soft cheese packed in modified atmosphere. Food Control 1998, 21, 136-142. [CrossRef]

12. Ross, R.P.; Morgan, S.; Hill, C. Preservation and fermentation: Past, present and future. Int. J. Food Microbiol. 2002, 79, 3-16. [CrossRef]

13. Stratford, M.; Steels, H.; Nebe-von-Caron, G.; Avery, S.V.; Novodvorska, M.; Archer, D.B. Population heterogeneity and dynamics in starter culture and lag phase adaptation of the spoilage yeast Zygosaccharomyces bailii to weak acid preservatives. Int. J. Food Microbiol. 2014, 181, 40-47. [CrossRef] [PubMed]

14. Brul, S.; Coote, P. Preservatives agents in foods: Mode of action and microbial resistance mechanisms. Int. J. Food Microbiol. 1999, 50, 1-17. [CrossRef]

15. Delavenne, E.; Cliquet, S.; Trunet, C.; Barbier, G.; Mounier, J.; Le Blay, G. Characterization of the antifungal activity of Lactobacillus harbinensis K.V9.3.1.Np and Lactobacillus rhamnosus K. C8.3.1I in yoghurt. Food Microbiol. 2015, 45, 10-17. [CrossRef] [PubMed]

16. Schoch, C.L.; Seifert, K.A.; Huhndorf, S.; Robert, V.; Spouge, J.L.; Levesque, C.A.; Chen, W. Nuclear ribosomal internal transcribed spacer (ITS) region as a universal DNA barcode marker for fungi. Proc. Natl. Acad. Sci. USA 2012, 109, 6241-6246. [CrossRef] [PubMed]

17. Almeida, M.; Hébert, A.; Abraham, A.L.; Rasmussen, S.; Monnet, C.; Pons, N.; Delbès, S.; Loux, V.; Batta, J.M.; Leonard, P.; et al. Construction of a dairy microbial genome catalog opens new perspectives for the metagenomic analysis of dairy fermented products. BMC Genom. 2014, 15, 1257-1287. [CrossRef] [PubMed]

18. Callon, C.; Retureau, E.; Didienne, R.; Montel, M.-C. Microbial biodiversity in cheese consortia and comparative Listeria growth on surfaces of uncookes pressed cheeses. Int. J. Food Microbiol. 2014, 174, 98-109. [CrossRef] [PubMed]

19. Montel, M.-C.; Buchin, S.; Mallet, A.; Delbes-Paus, C.; Vuitton, D.A.; Desmasures, N.; Berthier, F. Traditional cheeses: Rich and diverse microbiota with associated benefits. Int. J. Food Microbiol. 2014, 177, 136-154. [CrossRef] [PubMed]

20. Wolfe, B.E.; Button, J.E.; Santarelli, M.; Dutton, R.J. Cheese rind communities provide tractable systems for in situ and in vitro studies of microbial diversity. Cell 2014, 158, 422-433. [CrossRef] [PubMed]

21. Quigley, L.; O'Sullivan, O.; Stanton, C.; Beresford, T.P.; Ross, R.P.; Fitzgerald, G.F.; Cotter, P.D. The complex microbiota of raw milk. FEMS Microbiol. Rev. 2013, 37, 664-698. [CrossRef] [PubMed]

22. Dugat-Bony, E.; Garnier, L.; Denonfoux, J.; Ferreira, S.; Sarthou, A.S.; Bonnarme, P.; Irlinger, F. Highlighting the microbial diversity of 12 French cheese varieties. Int. J. Food Microbiol. 2016, 238, 265-273. [CrossRef] [PubMed]

23. Lavoie, K.; Touchette, M.; St-Gelais, D.; Labrie, S. Characterization of the fungal microflora in raw milk and specialty cheeses of the province of Quebec. Dairy Sci. Technol. 2012, 92, 455-468. [CrossRef] [PubMed]

24. Marín, P.; Palmero, D.; Jurado, M. Occurrence of moulds associated with ovine raw milk and cheeses of the Spanish region of Castilla La Mancha. Int. J. Dairy Technol. 2015, 68, 565-572. [CrossRef] 
25. Vacheyrou, M.; Normand, A.C.; Guyot, P.; Cassagne, C.; Piarrous, R.; Bouton, Y. Cultivable microbial communities in raw cow milk and potential transfers from stables of sixteen French farms. Int. J. Food Microbiol. 2011, 146, 253-262. [CrossRef] [PubMed]

26. Fleet, G.H. Yeasts in dairy products. J. Appl. Bacteriol. 1990, 68, 199-211. [CrossRef] [PubMed]

27. Von Neubeck, M.; Baur, C.; Krewinkel, M.; Stoeckel, M.; Kranz, B.; Stressler, T.; Fisher, L.; Hinrichs, J.; Scherer, S.; Wenning, M. Biodiversity of refrigerated raw milk microbiota and their enzymatic spoilage potential. Int. J. Food Microbiol. 2015, 211, 57-65. [CrossRef] [PubMed]

28. Kure, C.F.; Skaar, I.; Brendehaug, J. Mould contamination in production of semi-hard cheese. Int. J. Food Microbiol. 2004, 93, 41-49. [CrossRef] [PubMed]

29. Beletsiotis, E.; Guikas, D.; Kalantzi, K. Incorporation of microbiological and molecular methods in HACCP monitoring scheme of molds and yeasts in a Greek dairy plant: A case study. Proc. Food Sci. 2011, 1, 1051-1059. [CrossRef]

30. Temelli, S.; Anar, S.; Sen, C.; Akyuva, P. Determination of microbiological contamination sources during Turkish white cheese production. Food Control 2006, 17, 856-861. [CrossRef]

31. Oyugi, E.; Buys, E.M. Microbiological quality of shredded Cheddar cheese packaged in modified atmospheres. Int. J. Dairy Technol. 2007, 60, 89-95. [CrossRef]

32. Bokulich, N.A.; Mills, D.A. Facility-specific "house" microbiome drives microbial landscape of artisan cheesemaking plants. Appl. Environ. Microbiol. 2013, 79, 5214-5223. [CrossRef] [PubMed]

33. Radha, K.; Nath, L.S. Studies on the air quality in a dairy processing plant. Ind. J. Vet. Anim. Sci. Res. 2014, 43, 346-353. [CrossRef]

34. Schön, K.; Schornsteiner, E.; Dzieciol, M.; Wagner, M.; Müller, M.; Schmitz-Esser, S. Microbial communities in dairy processing environment floor-drains are dominated by product-associated bacteria and yeasts. Food Control 2016, 70, 210-215. [CrossRef]

35. Kaminarides, S.E.; Lakos, N.S. Yeasts in factory brine of feta cheese. Aust. J. Dairy Technol. 1992, 47, 68-71.

36. Suriyarachchi, V.R.; Fleet, G.H. Occurrence and growth of yeasts in yoghurts. Appl. Environ. Microbiol. 1981, 42, 574-579. [CrossRef] [PubMed]

37. Mayoral, M.B.; Martin, R.; Sanz, A.; Hernandez, P.E.; Gonzalez, I.; Garcia, T. Detection of Kluyveromyces marxianus and other spoilage yeasts in yoghurt using a PCR-culture technique. Int. J. Food. Microbiol. 2005, 105, 27-34. [CrossRef] [PubMed]

38. Penney, V.; Henderson, G.; Blum, C.; Johnson-Green, P. The potential phytopreservatives and nisin to control microbial spoilage of minimally processed fruit yoghurts. Innov. Food Sci. Emerg. Technol. 2004, 5, 369-375. [CrossRef]

39. Tranquillini, R.; Scaramuzza, N.; Berni, E. Occurrence and ecological distribution of heat resistant moulds spores (HRMS) in raw materials used by food industry and thermal characterization of two Talaromyces isolates. Int. J. Food Microbiol. 2017, 242, 116-123. [CrossRef] [PubMed]

40. Catellani, P.; Miotti Scapin, R.; Alberghini, L.; Radu, I.L.; Giaccone, V. Levels of microbial contamination of domestic refrigerators in Italy. Food Control 2014, 42, 257-262. [CrossRef]

41. Carreira, A.; Ferreira, L.M.; Loureiro, V. Brown pigments produced by Yarrowia lipolytica result from extracellular accumulation of homogentisic acid. Appl. Environ. Microbiol. 2001, 67, 3463-3468. [CrossRef] [PubMed]

42. Carreira, A.; Ferreira, L.M.; Loureiro, V. Production of brown tyrosine pigments by the yeast Yarrowia lipolytica. J. Appl. Microbiol. 2001, 90, 372-379. [CrossRef] [PubMed]

43. Dalgaard, P.; Gram, L.; Huss, H.H. Spoilage and shelf life of cod fillets packed in vacuum or modified atmospheres. Int. J. Food Microbiol. 1993, 19, 283-294. [CrossRef]

44. Gardini, F.; Tofalo, R.; Belleti, N.; Iucci, L.; Suzzi, G.; Torriani, S.; Guerzoni, M.E.; Lanciotti, R. Characterization of yeasts involved in the ripening of Pecorino Crotone cheese. Food Microbiol. 2006, 23, 641-648. [CrossRef] [PubMed]

45. Roig-Sagués, A.X.; Molina, A.P.; Hernàndez-Herrero, M. Histamine and tyramine-forming microorganisms in Spanish traditional cheeses. Eur. Res. Technol. 2002, 215, 69-100. [CrossRef]

46. Suzzi, G.; Schirone, M.; Martuscelli, M.; Gatti, M.; Fornasari, M.E.; Neviani, E. Yeasts associated with Manteca. FEMS Yeast Res. 2003, 3, 159-166. [CrossRef]

47. Linares, D.M.; Martín, M.C.; Ladero, V.; Álvarez, M.A.; Fernández, M. Biogenic amines in dairy products. Crit. Rev. Food Sci. Nutr. 2011, 51, 691-703. [CrossRef] [PubMed] 
48. Leuschner, R.G.; Heidel, M.; Hammes, W.P. Histamine and tyramine degradation by food fermenting microorganisms. Int. J. Food Microbiol. 1998, 39, 1-10. [CrossRef]

49. Garnier, L.; Valence, F.; Pawtowski, A.; Auhustsinava-Galerne, L.; Frotté, N.; Baroncelli, R.; Deniel, F.; Coton, E.; Mounier, J. Diversity of spoilage fungi associated with French dairy products. Int. J. Food Microbiol. 2017, 241, 191-197. [CrossRef] [PubMed]

50. Robinson, R.K. Dairy microbiology. In The Microbiology of Milk, 2nd ed.; Literary Cat Books: London, UK; New York, NY, USA, 1990; Volume 1, ISBN 978-0-471-38596-7.

51. Minervini, F.; Montagna, M.T.; Spilotros, G.; Monaci, L.; Santacroce, M.P.; Visconti, A. Survey on mycoflora of cow and buffalo dairy products from Southern Italy. Int. J. Food Microbiol. 2001, 69, 141-146. [CrossRef]

52. Jakobsen, M.; Narchus, J. Yeasts and their possible beneficial and negative effects on the quality of dairy products. Int. Dairy J. 1996, 6, 755-768. [CrossRef]

53. Fleet, G.H.; Mian, M.A. The occurrence and growth of yeasts in dairy products. Int. J. Food Microbiol. 1987, 4, 145-155. [CrossRef]

54. Hocking, A.D.; Faedo, M. Fungi causing thread mould spoilage of vacuum packaged Cheddar cheese during maturation. Int. J. Food Microbiol. 1992, 16, 123-130. [CrossRef]

55. Fadda, M.E.; Cosentino, S.; Deplano, M.; Palmas, F. Yeasts populations in Sardinian feta cheese. Int. J. Food Microbiol. 2001, 69, 153-156. [CrossRef]

56. Montagna, M.T.; Santacroce, M.P.; Spilotros, G.; Napoli, C.; Minervini, F.; Papa, A.; Dragoni, I. Investigation of fungal contamination in sheep and goat cheeses in southern Italy. Mycopathologia 2004, 158, 245-249. [CrossRef] [PubMed]

57. Jodral, M.; Liñan, E.; Acosta, I.; Gallego, C.; Roja, F.; Bentabol, A. Mycoflora and toxigenic Aspergillus flavus in Spanish milks. Int. J. Food Microbiol. 1993, 36, 171-174. [CrossRef]

58. Sensidoni, A.; Rondinini, G.; Peressini, D.; maifreni, M.; Bortolomeazzi, R. Presence of an off-flavor assiocated with the use of sorbates in cheese and margarine. Int. J. Food Sci. 1994, 6, 237-242.

59. Lund, F.; Filtenborg, O.; Frisvad, J.C. Associated mycoflora of cheese. Food Microbiol. 1995, 12, $173-180$. [CrossRef]

60. Houbraken, J.; Samson, R.A. Phylogeny of Penicillium and the segregation of Trichocomoceae into three families. Stud. Mycol. 2011, 70, 1-51. [CrossRef] [PubMed]

61. Frisvad, J.C.; Houbraken, J.; Popma, S.; Samson, R.A. Two new Penicillium species Penicillium buchwaldii and Penicillium spathulatum, producing the anticancer compound asperphenamate. FEMS Microbiol. Lett. 2013, 339, 77-92. [CrossRef] [PubMed]

62. Samson, R.; Frisvad, J.; Hoekstra, E.; Filtenborg, O. Introduction to food and airborne fungi. In Mycopathologia, 6th ed.; Centraal Bureau Voor Schimmelcultures: Utrecht, The Netherlands, 2002; p. 609, ISBN 109070351528.

63. Moubasher, A.H.; Abdel-Kader, M.I.A.; El-Kady, I.A. Toxigenic fungi isolated from Roquefort cheese. Mycopathologia 1978, 66, 187-190. [CrossRef]

64. Kikoku, Y.; Tagashira, N.; Nakano, H. Heat resistance of fungi isolated from frozen blueberries. J. Food Prot. 2008, 71, 2030-2035. [CrossRef] [PubMed]

65. Kure, C.F.; Wasteson, Y.; Brendehaug, J.; Skaar, I. Mould contaminants on Jarlsberg and Norvegia cheese blocks from four factories. Int. J. Food Microbiol. 2001, 70, 21-27. [CrossRef]

66. Bullerman, L.B.; Olivigni, L.B. Mycotoxin producing-potential of molds isolated from cheddar cheese. J. Food Sci. 1974, 39, 1166-1168. [CrossRef]

67. Hassanin, I.N. Detection of mycotoxigenic fungi and bacteria in processed cheese in Egypt. Int. Biodeterior. Biodegrad. 1993, 31, 15-23. [CrossRef]

68. Aran, N.; Eke, D. Mould mycoflora of Kaşar cheese at the stage of consumption. Food Microbiol. 1987, 4, 101-104. [CrossRef]

69. Kure, C.F.; Skaar, I. Mould growth on Norwegian semi-hard cheeses Norvegia and Jarlsberg. Int. J. Food Microbiol. 2000, 62, 133-137. [CrossRef]

70. Basílico, J.C.; deBasílico, M.Z.; Chiericatti, C.; Vinderola, C.G. Characterizaion and control of thread mould in cheese. Lett. Appl. Microbiol. 2001, 32, 419-423. [CrossRef] [PubMed]

71. Gould, G.W. Mechanisms of Action of Food Preservation Procedures; Gould, G.W., Ed.; Elsevier Applied Science: London, UK, 1989; ISBN 1851662936, 9781851662937.

72. Rahman, M.S. Handbook of Food Preservation, 2nd ed.; CRC Press: Boca Raton, FL, USA, 2007; ISBN 9781574446067. 
73. Sofos, J.N. Current microbiological considerations in food preservation. Int. J. Food Microbiol. 1993, 19, 87-108. [CrossRef]

74. Dalié, D.K.D.; Deschamps, A.M.; Richard-Forget, F. Lactic acid bacteria-Potential for control of mould growth and mycotoxins: A review. Food Control 2010, 21, 370-380. [CrossRef]

75. Regulation (EC) No. 852/2004 of the European Parliament and of the Council of 29 April 2004 on the Hygiene and Foodstuffs. Available online: http:/ / eur-lex.europa.eu/LexUriServ/LexUriServ.do?uri=OJ:L: 2004:139:0001:0054:en:PDF (accessed on 27 July 2017).

76. Rysstad, G.; Kolstad, J. Extended shelf life milk-Advances in technology. Int. J. Dairy Technol. 2006, 85-96. [CrossRef]

77. Loureiro, V.; Malfeito-Ferreira, M. Spoilage yeasts in foods and beverages: Characterization and ecology for improved diagnosis and control. Food Res. Int. 2000, 33, 247-256. [CrossRef]

78. Loureiro, V.; Querol, A. The prevalence and control of spoilage yeasts in foods and beverages. Trends Food Sci. Technol. 1999, 10, 356-365. [CrossRef]

79. Odet, G. Qualité bactériologique des fromages au lait cru. Cahiers de Nutrition et de Diététique 1999, 34, 47-53.

80. Faye, B.; Loiseau, G. Sources of Contamination in Dairy Supply Chains and Approaches to Quality Control; Paper Read at International Cooperation in International Research for Agricultural Development (CIRAD)-FAO: Montpellier, France, 2002; ISBN 92-5-004787-8.

81. Sandrou, D.K.; Arvanitoyannis, I.S. Implementation of Hazard Analysis Critical Control Point (HACCP) to the dairy industry: Current status and perspectives. Food Rev. Int. 2000, 16, 77-111. [CrossRef]

82. De Steur, H.; Wesana, J.; Dora, M.K.; Pearce, D.; Gellynck, X. Applying value stream mapping to reduce food losses and wastes in supply chains: A systematic review. Waste Manag. 2016, 58, 359-368. [CrossRef] [PubMed]

83. Pinto, A.T.; Schmidt, V.; Raimundo, S.A.; Raihmer, F. Use of ozone to control fungi in a cheese ripening room. Acta Sci. Vet. 2007, 35, 333-337. [CrossRef]

84. Serra, R.; Abrunhosa, L.; Kozakiewicz, Z.; Venâncio, A.; Lima, N. Use of ozone to reduce molds in a cheese ripening room. J. Food Prot. 2003, 66, 2355-2358. [CrossRef] [PubMed]

85. Varga, L.; Szigeti, J. Use of ozone in the dairy industry: A review. Int. J. Dairy Technol. 2016, 69, 157-168. [CrossRef]

86. Korukluoglu, M.; Sahan, Y.; Yigit, A. The fungicidal efficacy of various commercial disinfectants used in the food industry. Ann. Microbiol. 2006, 56, 325-330. [CrossRef]

87. Bundgaard-Nielsen, K.; Nielsen, P.V. Fungicidal effect of 15 disinfectants against 25 fungal contaminants commonly found in bread and cheese manufacturing. J. Food Prot. 1995, 59, 268-275. [CrossRef]

88. Martin, H.; Maris, P. Synergism between hydrogen peroxide and seventeen acids against five agri-food-borne fungi and one yeast strain. J. Appl. Microbiol. 2012, 113, 1451-1460. [CrossRef] [PubMed]

89. Lado, B.H.; Yousef, A.E. Alternative food-preservation technologies: Efficacy and mechanisms. Microbes Infect. 2002, 4, 433-440. [CrossRef]

90. European Union Council Directive 92/46/EEC of 16 June 1992 Laying Down the Health Rules for the Production and Placing on the Market or Raw Milk, Heat-Treated Mil and Milk-Based Products. Available online: https: / / www.fsvps.ru/fsvps-docs/ru/usefulinf/files/es9246.pdf (accessed on 27 July 2017).

91. Sakkas, L.; Moutafi, A.; Moschopoulou, E.; Moatsou, G. Assessment of treatment of various types of milk. Food Chem. 2014, 15, 293-301. [CrossRef] [PubMed]

92. Houbraken, J.; Samson, R.A.; Frisvad, J.C. Byssochlamys: Significance of heat resistance and mycotoxin production. In Advances in Food Mycology; Hocking, A.D., Pitt, J.I., Samson, R.A., Thrane, U., Eds.; Springer: New York, NY, USA, 2005; pp. 211-224.

93. Scaramuzza, N.; Berni, E. Heat-resistance of Hamigera avellanea and Thermoascus crustaceus isolated from pasteurized acid products. Int. J. Food Microbiol. 2014, 169, 63-68. [CrossRef] [PubMed]

94. Salomão, B.C.M.; Slongo, A.P.; Aragão, G.M.F. Heat resistance of Neosartorya fischeri in various juices. LWT Food Sci. Technol. 2007, 40, 676-680. [CrossRef]

95. Trujillo, A.J.; Capellas, M.; Saldo, J.; Gervilla, R.; Guamis, B. Applications of high-hydrostatic pressure on milk and dairy products: A review. Innov. Food Sci. Emerg. Technol. 2002, 3, 295-307. [CrossRef]

96. Mainville, I.; Montpetit, D.; Durand, N.; Farnworth, E.R. Deactivating the bacteria and yeast in kefir using heat treatment, irradiation and high pressure. Int. Dairy J. 2001, 11, 45-49. [CrossRef] 
97. Reps, A.; Krzyzewska, A.; Lanievska-Moroz, L.; Iwanczak, M. Effect of high pressure on microflora of kefir. In Proceedings of the First International Conference on High Pressure Bioscience and Biotechnology HPBB-2000, Kyoto, Japan, 26-30 November 2000; Volume 19, pp. 1-652. [CrossRef]

98. Evert-Arriagada, K.; Hernández-Herrero, M.M.; Guamis, B.; Trujillo, A.J. Commercial application of high-pressure processing for increasing starter-free fresh cheese shelf-life. Food Sci. Technol. 2014, 55, 498-505. [CrossRef]

99. Ravishankar, S.; Zhang, H.; Kempkes, M.L. Pulsed electric fields. Food Sci. Technol. Int. 2008, 14, 429-432. [CrossRef]

100. Buckow, R.; Scott Chandry, P.; Ng, S.Y.; McAuley, C.M.; Swanson, B.G. Opportunities and challenges in pulse electric field processing of dairy products. Int. Dairy J. 2014, 34, 199-212. [CrossRef]

101. Wan, J.; Coventry, J.; Swiergon, P.; Sanguansri, P.; Viersteeg, C. Advances in innovative processing technologies for microbial inactivation and enhancement of food safety-Pulsed electric field and low temperature plasma. Trends Food Sci. Technol. 2009, 20, 414-424. [CrossRef]

102. Gougouli, M.; Kalantzi, K.; Beletsiotis, E.; Koutsoumanis, K.P. Development and application of predictive models for fungal growth as tools to improve quality control in yoghurt production. Food Microbiol. 2011, 28, 1453-1462. [CrossRef] [PubMed]

103. Sandhya. Modified atmosphere packaging of fresh produce: Currentstatus and future needs. Food Sci. Technol. 2010, 43, 381-392. [CrossRef]

104. Ooraikul, B.; Stiles, M.E. Modified Atmosphere Packaging of Food; Ellis Horwood Publishing: New York, NY, USA, 1991; ISBN 978-0-7476-0064-0.

105. Nguyen Van Long, N.; Joly, C.; Dantigny, P. Active packaging with antifungal activities. Int. J. Food Microbiol. 2016, 220, 73-90. [CrossRef] [PubMed]

106. Rodriguez-Aguilera, R.; Oliveira, J.C.; Montanez, J.C.; Mahajan, P.V. Effect of modified atmosphere packaging on quality factors and shelf-life of surface mould ripened cheese: Part II varying storage temperature. LWT Food Sci. Technol. 2011, 44, 330-336. [CrossRef]

107. Sing, P.; Wani, A.A.; Karim, A.A.; Langowski, H.-C. The use of carbon dioxide in the processing and packaging of milk and dairy products: A review. Int. J. Dairy Technol. 2012, 65, 161-177. [CrossRef]

108. Hotchkiss, J.H.; Werner, B.G.; Lee, E.Y.C. Addition of carbon dioxide to dairy products to improve quality: A comprehensive review. Compr. Rev. Food Sci. Food Saf. 2006, 5, 158-168. [CrossRef]

109. Gonzalez-Fandos, E.; Sanz, S.; Olarte, C. Microbiological, physicochemical and sensory characteristics of Cameros cheese packaged under modified atmospheres. Food Microbiol. 2000, 17, 407-414. [CrossRef]

110. Taniwaki, M.H.; Hocking, A.D.; Pitt, J.I.; Fleet, G.H. Growth and mycotoxin production by fungi in atmosphere containing $80 \%$ carbon dioxide and 20\% oxygen. Int. J. Food Microbiol. 2010, 143, 218-225. [CrossRef] [PubMed]

111. Khoshgozaran, S.; Azizi, M.H.; Bagheripoor-Fallah, N. Evaluating the effect of modified atmosphere packaging on cheese characteristics: A review. Dairy Sci. Technol. 2012, 92, 1-24. [CrossRef]

112. Taniwaki, M.H.; Hocking, A.D.; Pitt, J.I.; Fleet, G.H. Growth and mycotoxin production by food spoilage under high carbon dioxide and low oxygen atmospheres. Int. J. Food Microbiol. 2009, 132, 100-108. [CrossRef] [PubMed]

113. Dermiki, M.; Ntzimani, A.; Badeka, A.; Savvaidis, I.N.; Kontominas, M.G. Shelf-life extension and quality attributes of the whey cheese "Myzithra Kalathaki" using modified atmosphere packaging. LWT Food Sci. Technol. 2008, 41, 284-294. [CrossRef]

114. Eliot, S.C.; Vuillemard, J.-C.; Edmond, J.-P. Stability of shredded Mozzarella cheese under modified atmospheres. J. Food Sci. 1998, 63, 1075-1080. [CrossRef]

115. Fedio, W.M.; Macleod, A.; Ozimek, L. The effect of modified atmosphere packaging on the growth of microorganisms in cottage cheese. Milchwissenschaft 1994, 49, 622-629.

116. Genigeorgis, C. Microbial and safety implications of the use of modified atmospheres to extend the storage life of fresh meat and fish. Int. J. Food Microbiol. 1985, 1, 237-251. [CrossRef]

117. Phillips, C.A. Review: Modified atmosphere packaging and its effects on the microbiological quality and safety of produce. Int. J. Food Sci. Technol. 1996, 31, 463-479. [CrossRef]

118. Rodriguez-Aguilera, R.; Oliveira, J.C.; Montanez, J.C.; Mahajan, P.V. Effect of modified atmosphere packaging on quality factors and shelf-life of surface mould ripened cheese: Part I constant temperature. LWT Food Sci. Technol. 2011, 44, 337-342. [CrossRef] 
119. Blocher, J.C.; Busta, F.F. Multiple modes of inhibition of spore germination and outgrowth by reduced $\mathrm{pH}$ and sorbate. J. Appl. Bacteriol. 1985, 59, 469-478. [CrossRef] [PubMed]

120. Guynot, M.E.; Ramos, A.J.; Sanchis, V.; Marín, S. Study of benzoate, propionate, and sorbate salts as mould spoilage inhibitors on intermediate moisture bakery products of low $\mathrm{pH}$ (4.5-5.5). Int. J. Food Microbiol. 2005, 101, 161-168. [CrossRef] [PubMed]

121. Huang, Y.; Wilson, M.; Chapman, B.; Hocking, A.D. Evaluation of the efficacy of four weak acids as antifungal preservatives in low-acid intermediate moisture model food systems. Food Microbiol. 2009, 27, 6-33. [CrossRef] [PubMed]

122. Stratford, M.; Nebe-von-Caron, G.; Steels, H.; Novodvorska, M.; Ueckert, J.; Archer, D.B. Weak-acid preservatives: $\mathrm{pH}$ and proton movements in the yeast Saccharomyces cerevisiae. Int. J. Food Microbiol. 2013, 161, 164-171. [CrossRef] [PubMed]

123. Fajardo, P.; Martins, J.T.; Fuciños, C.; Pastrana, L.; Teixera, J.A.; Vicente, A.A. Evaluation of a chitosan-based edible film as carrier of natamycin to improve the storability of Saloio cheese. J. Food Eng. 2010, 101, 349-356. [CrossRef]

124. EFSA. Scientific Opinion on the use of Natamycin (E 235) as a food additive. EFSA Panel on Food Additives and Nutrient Sources added to Food (ANS). EFSA J. 2009, 7, 1412. [CrossRef]

125. FDA (2015). ICFSAN/Office of Food Additive Safety. GRAS Notice Natamycin. Published: 6 November 2015. Response Letter GRAS Notice No. GRN 000578. Available online: https://www.fda.gov/Food/ IngredientsPackagingLabeling/GRAS/NoticeInventory/ucm484505.htm (accessed on 27 July 2017).

126. Brandão, L.R.; Rosa, J.C.C.; Nicoli, J.R.; Almeida, M.V.S.; do Carmo, A.P.; Queiros, H.T.; Castro, I.M. Investigating acid stress response in different Saccharomyces strains. J. Mycol. 2014, 12, 1-9. [CrossRef]

127. Ullah, A.; Chandrasekaran, G.; Brul, S.; Smits, J.G. Yeast adaptation to weak acids prevents futile energy expenditure. Front. Microbiol. 2013, 4, 1-10. [CrossRef] [PubMed]

128. Casas, E.; Ancos, B.; Valderrama, M.J.; Cano, P.; Peinado, J.M. Pentadiene production from potassium sorbate by osmotolerant yeasts. Int. J. Food Microbiol. 2004, 94, 93-96. [CrossRef] [PubMed]

129. Plumridge, A.; Stratford, M.; Lowe, K.C.; Archer, D.B. The weak-acid preservative sorbic acid is decarboxylated and detoxified by a phynylacrylic acid decarboxylase, PadA1, in the spoilage mold Aspergillus niger. Appl. Environ. Microbiol. 2008, 74, 550-552. [CrossRef] [PubMed]

130. Kallinteri, L.D.; Kostoula, O.K.; Savvaidis, I.N. Efficacy of nisin and/or natamycin to improve the shelf-life of Galotyri cheese. Food Microbiol. 2013, 36, 176-181. [CrossRef] [PubMed]

131. De Oliveira, T.M.; De Fátima Ferreira Soares, N.; Pereira, R.M.; De Freitas Fraga, K. Development and evalutation of antimicrobial natamycin-incorporated film in Gorgonzola cheese conservation. Packag. Technol. Sci. 2007, 20, 147-153. [CrossRef]

132. Ollé Resa, C.P.; Gerschenson, L.N.; Jagus, R.J. Natamycin and nisin supported on starch edible films for controlling mixed growth on model systems and Port Salut cheese. Food Control 2014, 44, 146-151. [CrossRef]

133. Ollé Resa, C.P.; Jagus, R.J.; Gerschenson, L.N. Natamycin effiency for controlling yeast growth in models systems and on cheese surfaces. Food Control 2014, 35, 101-108. [CrossRef]

134. WHO. Safety Evaluation of Certain Food Additives and Contaminants; Natamycin (Pimaricin); WHO Food Additives Series 48; WHO: Geneva, Switzerland, 2002. Available online: http://apps.who.int/iris/ bitstream/10665/42578/1/WHO_TRS_909.pdf (accessed on 27 July 2017).

135. Van Leeuwen, M.R.; De Boer, W.; Smant, W.; Dijksterhuis, J. Filipin is a reliable in situ marker of ergosterol in the plasma membrane of germinating conidia (spores) of Penicillium discolor and stains intensively at the site of germ tube formation. J. Microbiol. Methods 2008, 74, 64-73. [CrossRef] [PubMed]

136. Van Leeuwen, M.R.; Van Doorn, T.; Golovina, E.A.; Stark, J.; Dijksterhuis, J. Waterand air-distributed conidia exhibit differences in sterol content and cytoplasmic microviscosity. Appl. Environ. Microbiol. 2010, 67, 366-369. [CrossRef] [PubMed]

137. Stern, G.A. In vitro antibiotic synergism against ocular fungal isolates. Am. J. Ophthalmol. 1978, 86, 359-367. [CrossRef]

138. Streekstra, H.; Verkennis, A.E.E.; Jacobs, R.; Dekker, A.; Stark, J.; Dijksterhuis, J. Fungal strain and the development of tolerance against natamycin. Int. J. Food Microbiol. 2016, 238, 15-22. [CrossRef] [PubMed] 
139. Joint FAO/WHO Expert Committee on Food Additives. Evaluation of Certain Food Additives and Contaminants: 67th Report of the Joint FAO/WHO Expert Committee on Food Additives; WHO Technical Report Series; WHO: Geneva, Switzerland, 2007; p. 25. Available online: http://www.who.int/ipcs/publications/jecfa/reports/ trs940.pdf (accessed on 27 July 2017).

140. Bourdichon, F.; Casaregola, S.; Farrokh, C.; Frisvad, J.C.; Gerds, M.L.; Hammes, W.P.; Harnett, J.; Huys, G.; Laulund, S.; Ouwehand, A.; et al. Food fermentations: Microorganisms with technological beneficial use. Int. J. Food Microbiol. 2012, 154, 87-97. [CrossRef] [PubMed]

141. Caplice, E.; Fitzgerald, G.F. Food fermentations: Role of microorganisms in food production and preservation. Int. J. Food Microbiol. 1999, 50, 131-149. [CrossRef]

142. Brimelow, C.J.B.; Collins-Thompson, D. Food preservatives. Food Control 1992, 3, 218-219. [CrossRef]

143. Elsser-Gravesen, D.; Elsser-Gravesen, A. Biopreservatives. In Biotechnology of Food and feed Additives; Zorn, H., Czermak, P., Eds.; Springer: Berlin, Germany, 2014; ISBN 978-3-662-43761-2.

144. Stiles, M.E. Biopreservation by lactic acid bacteria. Antonie van Leeuwenhoek 1996, 70, 331-345. [CrossRef] [PubMed]

145. Holzapfel, W.H.; Geisen, R.; Schillinger, U. Biological preservation of foods with reference to protective cultures, bacteriocins and food-grade enzymes. Int. J. Food Microbiol. 1995, 24, 343-362. [CrossRef]

146. Magnusson, J.; Schnurer, J. Lactobacillus coryniformis subs. coryniformis strain Si3 produces a broad-spectrum proteinaceous antfungal compound. Appl. Environ. Microbiol. 2001, 67, 1-5. [CrossRef] [PubMed]

147. Lassois, L.; de Lapeyre de Bellaire, L.; Jijakli, M.H. Biological control of crown rot of bananas with Pichia anomala strain K and Candida oleophila strain O. Biol. Control 2008, 45, 410-418. [CrossRef]

148. Zhang, H.; Wang, L.; Ma, L.; Dong, Y.; Jiang, S.; Xu, B.; Zheng, X. Biocontrol of major postharvest pathogens on apple using Rhodotorula glutinis and its effects on postharvest quality parameters. Biol. Control 2009, 48, 79-83. [CrossRef]

149. Carr, F.J.; Chill, D.; Maida, N. The lactic acid bacteria: A literature survey. Crit. Rev. Microbiol. 2002, 28, 281-370. [CrossRef] [PubMed]

150. Schwenninger, S.M.; Meile, L. A mixed culture of Propionibacterium jensenii and Lactobacillus paracasei subs. paracasei inhibits food spoilage yeasts. Syst. Appl. Microbiol. 2004, 27, 229-237. [CrossRef] [PubMed]

151. Aljewicz, M.; Cichosz, G. Protective effects of Lactobacillus cultures in Dutch-type cheese like products. LWT Food Sci. Technol. 2015, 63, 52-56. [CrossRef]

152. Aunsbjerg, S.D.; Honoré, A.H.; Marcussen, J.; Ebrahimi, P.; Vogensen, F.K.; Benfeldt, C.; Skov, T.; KnØchel, S. Contribution of volatiles to the antifungal effect of Lactobacillus paracasei in defined medium and yoghurt. Int. J. Food Microbiol. 2015, 194, 46-53. [CrossRef] [PubMed]

153. Crowley, S.; Mahony, J.; van Sinderen, D. Curent perspectives on antifungal lactic acid bacteria as natural bio-preservatives. Trends Food Sci. Technol. 2013, 33, 93-109. [CrossRef]

154. Inglin, R.C.; Stevens, M.J.A.; Meile, L.; Lacroix, C.; Meile, L. High-throughput screening assays for antibacterial and antifungal activities of Lactobacillus species. J. Microbiol. Methods 2015, 114, 26-29. [CrossRef] [PubMed]

155. Stiles, J.; Penkar, S.; Plocková, M.; Chumchalová, J.; Bullerman, L.B. Antifungal activity of sodium acetate and Lactobacillus rhamnosus. J. Food Prot. 2002, 65, 1188-1191. [CrossRef] [PubMed]

156. Le Lay, C.; Mounier, J.; Vasseur, V.; Weill, A.; Le Blay, G.; Barbier, G.; Coton, E. In vitro and in situ screening of lactic acid bacteria and propionibacteria antifungal activities against bakery product spoilage molds. Food Control 2016, 60, 247-255. [CrossRef]

157. Delavenne, E.; Mounier, J.; Deniel, F.; Barbier, G.; Le Blay, G. Biodiversity of antifungal lactic acid bacteria isolated from raw milk samples from cow, ewe and goat over one-year period. Int. J. Food. Microbiol. 2012, 155, 185-190. [CrossRef] [PubMed]

158. Fernandez, B.; Vimon, A.; Desfossés-Foucault, E.; Daga, M.; Arora, G.; Fliss, I. Antifungal activity of lactic and propionic acid bacteria and their potential as protective culture in cottage cheese. Food Control 2017, 78, 350-356. [CrossRef]

159. Axelsson, L.; Chung, T.C.; Debrogosz, W.J.; Lindgren, S. Production of a broad spectrum antimicrobial substance by Lactobacillus reuteri. Microb. Ecol. Health Dis. 1989, 2, 131-136. [CrossRef]

160. Dagnas, S.; Gauvry, E.; Onno, B.; Membré, J.M. Quantifying effect of lactic, acetic, and propionic acids on growth of molds isolated from spoiled bakery products. J. Food Prot. 2015, 78, 1689-1698. [CrossRef] [PubMed] 
161. Coallier-Ascah, J.; Idziak, E.S. Interaction between Streptococcus lactis and Aspergillus flavus on production of aflatoxin. Appl. Environ. Microbiol. 1985, 49, 163-167. [CrossRef] [PubMed]

162. Luchese, R.H.; Harrigan, W.F. Growth of, and aflatoxin production by Aspergillus paraciticus when in the presence of either Lactococcus lactis or lactic acid and at different initial pH values. J. Bacteriol. 1990, 69, 512-519. [CrossRef]

163. Batish, V.K.; Roy, U.; Lal, R.; Grower, S. Antifungal attributes of lactic acid bacteria-A review. Crit. Rev. Biotechnol. 1997, 17, 209-225. [CrossRef] [PubMed]

164. Roy, U.; Batish, V.K.; Grover, S.; Neelakantan, S. Production of antifungal substance by Lactococcus lactis subsp. lactis CHD-28.3. Int. J. Food Microbiol. 1996, 32, 27-34. [CrossRef]

165. Florianowicz, T. Antifungal activity of some microorganisms against Penicillium expansum. Eur. Food Res. Technol. 2001, 212, 282-286. [CrossRef]

166. Voulgari, K.; Hatzikamari, M.; Delepoglou, A.; Georgakipoulos, P.; Litopoulou-Tzanetaki, E.; Tzanetakis, N. Antifungal activity of non-starter lactic acid bacteria isolates from dairy products. Food Control 2010, 21, 136-142. [CrossRef]

167. Garofalo, C.; Zannini, E.; Aquilanti, L.; Silvestri, G.; Fierro, O.; Picariello, G.; Clementi, F. Selection of sourdough lactobacilli with antifungal activity for use as biopreservatives in bakery products. J. Agric. Food Chem. 2012, 60, 7719-7728. [CrossRef] [PubMed]

168. Coda, R.; Rizello, C.G.; Nigri, F.; De Angelis, M.; Arnault, P.; Gobbetti, M. Long-term fungi inhibitory activity of water-soluble extract from Phaseolus vulgaris cv. pinto and sourdough lactic acid bacteria during bread storage. Appl. Environ. Microbiol. 2008, 74, 7391-7398. [CrossRef] [PubMed]

169. Gerez, C.L.; Torres, M.J.; Font de Valdez, G.; Rollán, G. Control of spoilage fungi by lactic acid bacteria. Biol. Control 2013, 64, 231-237. [CrossRef]

170. Mauch, A.; Dal Bello, F.; Coffey, A.; Arendt, E.K. The use of Lactobacillus brevis PS1 to in vitro inhibit the outgrowth of Fusarium culmorum and other common Fusarium species found on barley. Int. J. Food Microbiol. 2010, 141, 116-121. [CrossRef] [PubMed]

171. Falguni, P.; Shilpa, V.; Mann, B. Production of proteinaceous antifungal substances from Lactobacillus brevis NCDC. Int. J. Dairy Technol. 2010, 63, 70-76. [CrossRef]

172. Gourama, H. Inhibition of growth and mycotoxin production of Penicillium by Lactobacillus species. LWT Food Sci. Technol. 1997, 30, 279-283. [CrossRef]

173. Li, H.; Liu, L.; Zhang, S.; Uluko, H.; Cui, W.; Lv, J. Potential use of Lactobacillus casei AST18 as bioprotective culture in yoghurt. Food Control 2013, 34, 675-680. [CrossRef]

174. Atanassova, M.R.; Fernández-Otero, C.; Rodríguez-Alonso, P.; Fernández-No, I.C.; Garabal, J.I.; Centeno, J.A. Characterization of yeasts isolated from artisanal short-ripened cows' cheeses produced in Galicia (NW Spain). Food Microbiol. 2016, 53, 172-181. [CrossRef] [PubMed]

175. Ryan, L.A.; Zannini, E.; Dal Bello, F.; Pawlowska, A.; Koehler, P.; Arendt, E.K. Lactobacillus amylovorus DSM 19280 as a novel food-grade antifungal agent for bakery products. Int. J. Food Microbiol. 2011, 146, 276-283. [CrossRef]

176. Lynch, K.M.; Pawlowska, A.M.; Brosnan, B.; Coffey, A.; Zannini, E.; Furey, A.; McSweeney, P.L.H.; Waters, D.M.; Arendt, E.K. Application of Lactobacillus amylovorus as an antifungal adjunct to extend the shelf-life of Cheddar cheese. Int. J. Food Microbiol. 2014, 34, 167-173. [CrossRef]

177. Corsetti, A.; Gobetti, M.; Rossi, J.; Damiani, P. Antimould activity of sourdough lactic acid bacteria: Identification of a mixture of organic acids produced by Lactobacillus sanfrancisco CB1. Appl. Microbiol. Biotechnol. 1998, 50, 253-256. [CrossRef] [PubMed]

178. Corsetti, A.; Settani, L.; van Sinderen, D.; Felis, G.; Dellaglio, F.; Gobetti, M. Lactobacillus rossii sp. nov., isolated from wheat sourdough. Int. J. Syst. Evol. Microbiol. 2004, 55, 35-40. [CrossRef]

179. Muhialdin, B.J.; Hassan, Z.; Sadon, S.K.; Zulkifli, N.A.; Azfar, A.A. Effect of pH and heat treatment on antifungal activity of Lactobacillus fermentum TE007, Lactobacillus pentosus G004 and Pediococcus pentosaceus TE010. Innov. Romanian Food Biotechnol. 2011, 8, 41-53. [CrossRef]

180. Coloretti, F.; Carri, S.; Armaforte, E.; Chiavari, C.; Grazia, L.; Zambonelli, C. Antifungal activity of lactobacilli isolated from salami. FEMS Microbiol. Lett. 2007, 271, 245-250. [CrossRef] [PubMed]

181. Guo, J.; Mauch, A.; Galle, S.; Murphy, P.; Arendt, E.K.; Coffey, A. Inhibition of growth of Trichophyton tonsurans by Lactobacillus reuteri. J. Appl. Microbiol. 2011, 111, 474-483. [CrossRef] [PubMed] 
182. Niku-Paavola, M.L.; Laitila, A.; Mattila-Sandholm, T.; Haikara, A. New types of antimicrobial compounds produced by Lactobacillus plantarum. J. Appl. Microbiol. 1999, 86, 29-35. [CrossRef] [PubMed]

183. Dal Bello, F.; Clarke, C.; Ryan, L.; Ulmer, H.; Schober, T.; Strom, K.; Sjögren, J.; van Sinderen, D.; Schnürer, J.; Arendt, E.K. Improvement of the quality and shelf life of wheat bread by fermentation with the antifungal strain Lactobacillus plantarum FST 1.7. J. Cereal Sci. 2007, 45, 309-318. [CrossRef]

184. Lavermicocca, P.; Valerio, F.; Visconti, A. Antifungal activity of phenyllactic acid against molds isolated from Bakery products. Appl. Environ. Microbiol. 2003, 69, 634-640. [CrossRef] [PubMed]

185. Ström, K.; Sjogren, J.; Broberg, A.; Schnürer, J. Lactobacillus plantarum MiLAB 393 produces the antifungal cyclic dipeptides cyclo (L-Phe-L-Pro) and cyclo (L-Phe-trans-4-OH-L-Pro) and 3-phenyllactic acid. Appl. Environ. Microbiol. 2002, 68, 4322-4327. [CrossRef] [PubMed]

186. Sjogren, J.; Magnusson, J.; Broberg, A.; Schnu rer, J.; Kenne, L. Antifungal 3- hydroxy fatty acids from Lactobacillus plantarum MiLAB 14. Appl. Environ. Microbiol. 2003, 69, 7554-7557. [CrossRef] [PubMed]

187. Sathe, S.J.; Nawani, N.N.; Dhakephalkar, P.K.; Kapadnis, B.P. Antifungal lactic acid bacteria with potential to prolong shelf-life of fresh vegetables. J. Appl. Microbiol. 2007, 103, 2622-2628. [CrossRef] [PubMed]

188. Yang, E.J.; Chang, H.C. Purification of a new antifungal compound produced by Lactobacillus plantarum AF1 isolated from kimchi. Int. J. Food Microbiol. 2010, 139, 56-63. [CrossRef] [PubMed]

189. Prema, P.; Smila, D.; Palavesan, A.; Immanuel, G. Production and characterization of an antifungal compound (3-phenyllactic acid) produced by Lactobacillus plantarum strain. Food Bioprocess Technol. 2008, 3, 379-386. [CrossRef]

190. Rouse, S.; Harnett, D.; Vaughan, A.; Sinderen, D.V. Lactic acid bacteria with potential to eliminate fungal spoilage in foods. J. Appl. Microbiol. 2008, 104, 915-923. [CrossRef] [PubMed]

191. Ndagano, D.; Lamoureux, T.; Dortu, C.; Vandermoten, S.; Thonart, P. Antifungal activity of 2 lactic acid bacteria of the Weissella Genus Isolated from Food. J. Food Sci. 2011, 76, 305-311. [CrossRef] [PubMed]

192. Wang, H.; Sun, Y.; Chen, C.; Sun, Z.; Zhou, Y.; Shen, F. Genome shuffling of Lactobacillus plantarum for improving antifungal activity. Food Control 2013, 32, 341-347. [CrossRef]

193. Laitila, A.; Alakomi, H.L.; Raaska, L.; Mattila-Sandholm, T.; Haikara, A. Antifungal activities of two Lactobacillus plantarum strains against Fusarium moulds in vitro and in malting of barley. J. App. Microbiol. 2002, 93, 566-576. [CrossRef]

194. Digaitiene, A.; Hansen, A.; Juodeikiene, G.; Eidukonyte, D.; Josephsen, J. Lactic acid bacteria isolated from rye sourdoughs produce bacteriocin-like inhibitory substances active against Bacillus subtilis and fungi. J. Appl. Microbiol. 2012, 112, 732-742. [CrossRef] [PubMed]

195. Lind, H.; Jonsson, H.; Schnürer, J. Antifungal effect of dairy propionibacteria-contribution of organic acids. Int. J. Food Microbiol. 2003, 98, 157-165. [CrossRef] [PubMed]

196. Mieszkin, S.; Hymery, N.; Debaets, S.; Coton, E.; Le Blay, G.; Valence, F.; Mounier, J. Action mechanism involved in the bioprotective effect of Lactobacillus harbinensis K.V9.3.1Np against Yarrowia lipolytica in fermented milk. Int. J. Food Microbiol. 2017, 248, 47-55. [CrossRef] [PubMed]

197. Al-Zoreky, N.; Ayres, J.W.; Sandine, W.E. Antimicrobial activity of Microgard against food spoilage and pathogenic microorganisms. J. Dairy Sci. 1991, 74, 758-763. [CrossRef]

198. Daeschel, A.M. Antimicrobial substances from lactic acid bacteria for use as food preservatives. Food Technol. 1989, 43, 91-94. [CrossRef]

(C) 2017 by the authors. Licensee MDPI, Basel, Switzerland. This article is an open access article distributed under the terms and conditions of the Creative Commons Attribution (CC BY) license (http://creativecommons.org/licenses/by/4.0/). 